\title{
THE ‘RIGHT TO THE CITY’ ON VARIOUS SCALES
}

\author{
MAREK NOWAK ${ }^{1}$ \\ 1 Adam Mickiewicz University, Poznań, Szamarzewskiego 89 C, 60-568 Poznań, Poland. ORCID: \\ 0000-0003-1749-7669, Email: marek.nowak@amu.edu.pl
}

ABSTRACT: The introduction to this volume pursues two aims. On the one hand, it refers to the problem of distinguishing between 'right to the city' initiatives and 'urban city movements' as phenomena embedded in different structural moments of society. On the other hand, it attempts to propose a supplement to the discussion about the aforementioned phenomena. This supplement addresses the need to take into account different scales by which the phenomena of self-organisation in the city are analysed. The article offers an example of such analysis referring to the Central European and the Polish perspectives, treating the two stories as separate to a certain extent. As it turns out, each of them offers a slightly different reasoning and different contexts for understanding the evolution of phenomena as well as separate decisive factors shaping the empowerment processes. The reader finds here references to research analysis in sociology, urban and economic history, supplementing the existing knowledge. The proposed interpretation is intended to lead to a discussion on the need to comprehend local and regional specifics in universalising studies.

KEYWORDS: self-organisation, Central Europe experience, Polish self-organisation, urban city movements in Poland

\section{INTRODUCTION}

This volume of the Society Register contains a meta-theoretical reflection as an introduction, supplemented by a sketch of the historical analysis, as well as five texts on 
social self-organization in the cities. These articles are as follows: Barbara Lewenstein "Urban movements in the process of the legitimation of liberal democracy: analysis of the activities of alternative groups and civil organizations at a time of European crisis"; Fabio Corbisiero and Salvatore Monaco "The right to a rainbow city: the Italian gay social movements"; Paweł Kubicki "Inventing urbanity: urban movements in Poland”; Przemysław Pluciński “'Meeting of waters?' reconstructing the landscape of the polish right to the city activism." Finally, the last text in this volume is an attempt to expand the field of reflection on the subject of the 'right to the city' in a practical way by including discursive and spatial topics to the analysis: Renata Putkowska-Smoter and Jan Frankowski, "Right to the map? Counter-mapping practices of smog alerts and urban greenery movements in Poland.”

The introduction is divided into two parts: a preface containing a reference to the existing state of knowledge brought together around two problematic domains of 'urban social movements' and 'right to the city,' and a specific analysis inspired by the dissimilarity of the scales used in the descriptions of two phenomena converging with each other.

The key to the concept of the volume was to identify the premises of the distinction between 'urban social movements' and 'right to the city' and to analyse its sources not only on theoretical basis but with reference to historical analysis. This idea served the proposal to open a discussion that is more responsive to regional and 'local' conditions of individual societies. The presentation of the problem results from the empirical observation on the coexistence of at least three scales of analysis in scientific discourse that draw the reader's interest to slightly different stories, depending on the author's position and the scale to which they refer. The essence of the distinction here is partly the spatial context (the introduction will be often referring to Central Europe) however, to a greater extent it is a record of the understanding of the historical process rooted in space, allowing for conclusions about certain phenomena from the point of view of their causes and social consequences. This interpretation performs a paraphrase of 'scales' by referring to research in the field of social geography. (Marston 2000) In the meaning presented in this paper, a scale can be both size, specific level, and relation. A scale is primarily "a device by which to measure biophysical and social phenomena. Traditionally two scales are discerned: spatial and temporal.” (Padt \& Arts 2014) Following this definition, a similar strategy will be proved when it is possible in research practice to reach or measure modalities and establish that, in relation to individual areas (considered in the geographical and historical sense), people actually tell slightly different stories. The answer to the question 'why' (they would do it), apart from a cognitive reflection par excellence, includes also the aspect of self-knowledge and thus the postulate of expanding one's scientific worldview with perspectives that elude universalizing or 'meliorative' theoretical approach.

The so-called 'urban social movements' and 'right to the city' initiatives are becoming an increasingly important subject for researchers representing various disciplines: sociologists, social geographers, urban planners. Existing analysis suggest the universal character of both phenomena, although the authors often point out their local focus that suggests some sort of 'glocal' specificity. Levi-Strauss, and eventually 
Ernesto Laclau, propose categories of 'empty signifier' or 'floating signifier,' that can mean different things to different people. There is no doubt that in Europe, particularly in the southern and eastern part of the continent, both of them have become one of the key flagship-actors of social change (Jacobsson 2016; Pixova 2018; Jezierska \& Polańska 2018; Domaradzka 2018; Dolenec, Doolan, \& Tmmasevic 2017). As this volume discusses common elements and relations between different forms and subjects of urban self-organization, it is set out around a wide range of conceptualizations (for further references, see the volume of Voluntas from March 2018).

The main distinction between 'urban social movements' and 'right to a city' initiatives is sometimes perceived as artificial (Domaradzka 2018; Pluciński 2018) in the context of theoretical literary studies. Nevertheless, in the theoretical perspective proposed by the editor of the volume, it reflects the division that is 'real' (it concerns the ontology of social life). It can be seen in the conditions of Central and Eastern Europe, being the ones that are more familiar for the authors of the present volume. The evolution of Manuel Castells' position from his works The Urban Question: A Marxist Approach and The City and the Grassroots 1983 constitute an inspiration to emphasize the division into 'urban social movements' and 'right to the city' initiatives. It has also been inspired by Mark Purcell's view of rights to the city when he undertakes a description of Lefebvre's opinion on the subject (Purcell 2013), as well as Margit Mayer's position in the article The 'Right to the City' in the context of shifting mottos of urban social movements. (Mayer 2009) The latter (referring to Castells' opinion as well) does not however see a fundamental difference at the level of operationalisation of the concept of urban activism; it points more to a historical transition that took place in the second half of the 1970s, which is related to the evolution of capitalism:

as not only articulating the structural contradictions of late-capitalist societies but also as capable of bringing about, together with labour unions and political parties, fundamental change in politics and society. (Mayer 2009: 364)

The change that takes place a decade later is associated with progressive domination of neoliberalism (against the earlier dominance of Keynesian-welfarists) and the return of classical issues of class conflict. As she says:

this neo-liberalisation of policies brought the so-called 'old' social issues back on to the agenda of urban movements: increasing unemployment and poverty, a 'new' housing need, riots in housing estates and new waves of squattings changed the make-up of the urban movements, while local governments-confronted with intensifying fiscal constraints while expenditures were growingbecame interested in innovative ways to solve their problems. (Mayer 2009: 364)

The result of this reconfiguration is a change of the recipient of the protest and a change of strategies used by city movements 'from opposition to cooperation.' In a way, the essence of this transformation is the recognition of the subsidiarity principle, which is accompanied by a more or less universal tendency towards decentralization, also described as a 'subsidiarity policy' (Kazepov 2008). According to Mayer, a similar situation, or more precisely the ambiguity of the change: 
created a bifurcation between the more and more professionalized development and service delivery organizations on the one hand and groups, whose needs were not addressed by these arrangements and who in turn radicalized. (Mayer 2009: 364)

This process, due to political and social conditions, showed a tendency to different dynamics in various areas of Europe but as a result, the destiny of urban activism follows at least two paths. The first one leads towards contesting the changes introduced by deregulation; the other towards institutionalization and claims of having an influence on the whole process. Both refer to the strategy of the so-called new social movements, focusing not only on living issues or issues of collective consumption, but reaching spheres of self-realization and subjectivity in a cultural or universal meaning (such as ecological movements, fight against climate change or fight for the empowerment of sexual minorities, etc.). The strategies aiming the realisation of the objectives and the radicalism of the claims were, of course, definitely divergent for different environments included in this division, which resulted in disparate diagnoses and forecasts regarding the significance and evolution of the phenomenon. According to the author of the text, the above-mentioned rupture (as we mentioned before: the division into 'urban social movements' and 'right to a city' initiatives) is not only related to the recent history of the evolution of urban regimes towards professionalization and deregulation but has deeper historical sources. The aforementioned question 'why' is therefore crucial here.

The indicated axis of differentiation or tension is illustrated in this volume by a statement made by two Polish sociologists: Przemysław Pluciński and Paweł Kubicki. They were the direct inspiration for the proposed conceptualization. What is also important is the fact that the sources of this distinction are satisfactorily described by the researchers, although they tend to go in cognitively opposite directions. The proposed introduction is a form of supplement and thus filling in the research gap, which means proposing a broader integration ground for both positions. This idea goes beyond the interpretation of empirical conclusions. A researcher of the phenomenon of social self-organization has a sense (to which they succumb to or not) of the need to abstract from the accumulated state of knowledge about a specific phenomenon - on the scale of 'local' or 'regional' knowledge, which is often of fundamental importance for understanding the dynamics of a specific social process in a specific city. To avoid this discomfort and its cognitive consequences, the description of 'Right to the city movements' or 'Urban social city movements' should be: (a) multi-scaled (referring to the classical, 'universal' literature on social dynamics in the city but at the same time detached from it), (b) systemic (taking interdependencies into account) and, in a certain scope, (c) asynchronous (perceiving the internal 'historiosophical' dynamics of long-lasting processes). In the practice of constructing a scientific statement and constructing generalizations, this means establishing a distinction between scales of analysis. According to one of them, we analyse European phenomena as a basis for grasping the dynamics of a more or less universal process. One can find a perfect example of this attitude in Barbara Lewenstein's text from this volume: "Urban move- 
ments in the process of the legitimation of liberal democracy: analysis of the activities of alternative groups and civil organizations at a time of European crisis" which, being part of a wider European research project, places Polish experiences directly in the context of the consequences of the 2008-09 crisis and the crisis of democracy in Europe. (Lewenstein 2020) The second example is presented in the text by Fabio Corbisiero and Salvatore Monaco: "The right to a rainbow city: the Italian gay social movements" describing the evolution of the LGBT movement in Italy, compared to the processes that took place on a European scale. Accordingly to those articles, we have to analyse regional specificities on a different scale. Thus, in relation to Central and Southern Europe, we need to include references to the history of regions, the tradition of self-government or departure from authoritarian ruling over the last 50 years (Sava \& Pleyers 2016), as well as any other consequences of the systemic transformation from socialism to capitalism. Consequently, this attitude concerns a specifically defined area in the context of specific political events, such as the fall of the Berlin Wall or the collapse of Yugoslavia. The last scale is defined in relation to e.g. specific 'local' experiences; here we can find Polish narratives like the phenomenon of the Solidarity social movement. (Staniszkis 1984; Kubow 2013) In this volume, the study by Paweł Kubicki: "Inventing urbanity: urban movements in Poland" is a perfect example of a text constructed around this scale; it describes the process of the birth of urban movements in Poland over the last ten years or more, with reference to empirical data. (Kubicki 2020) Interestingly, the phenomena and processes from different scales clearly interact with each other, which is probably the most visible while noticing tendencies towards the Europeanization of scientific discourse, which directly affects public policies. It also allows for the phenomena occurring at the local level to be presented on a larger scale, as an expression of universal tendencies. An example of such approach is presented in the article by Przemysław Pluciński - available in this volume - which presents a different interpretation than Paweł Kubicki's study, concentrating on the sources of 'a right to the city' in Poland based on radical contexts.

Comparative references to the sociology of individual societies on a historical and systemic background were not often used in social self-organization analysis. A certain increase in interest in this problem en bloc occurred in the 1970s to 1990s due to the sociology of world-systems created by Immanuel Walerstein and his team; this problem was also present in the previous interpretations of the Fernand Braudel's school (Braudel 1970) and, for example, in Polish economic historians' works from the 1950s. (Bogucka 1981) Later, we can find this phenomenon in border studies - contemporary European borders and identity analysis. ${ }^{1}$ In the further part of the introduction, we attempt to describe the 'right to the city' on various scales, as well as to ask the question about differences concerning the Central European experience.

\footnotetext{
${ }^{1}$ There are two axes that define Europe's identity: the north-south axis and the east-west axis. The eastwest axis is not referred to as the central axis, although both the south and the east are treated as a kind of periphery. (cf. Eder 2006; Brzechczyn 2020: 41-56) Therefore, the interpretative perspective relates more to social geography than to historical sociology.
} 


\section{THE 'RIGHT TO THE CITY' ON VARIOUS SCALES. A QUESTION ABOUT THE DIVERGENCE OF THE POLISH EXPERIENCE}

The issues of description scales and the interpretative consequences resulting from the use of specific research tools can be best analysed by referring to particular phenomena and propositions of a certain narrative. In this case, we propose to focus on the problem of factors influencing the dynamics of class-profiled social self-organisation, the latter being treated synonymously with the concept of 'right to the city.' Firstly, we refer to the universalizing European scale with reference to the 'meeting of the waters' metaphor. Then, we point out selected historical foundations for differentiating the 'right to the city' on the Central-European scale, in order to complete our analysis with the longue durée perspectives - on the scale of a specific society (referring here to Polish experiences).

The starting point for this last part will be to indicate the genetic context of self-organisation in the territories of the First Republic of Poland, in the form of four generalisations having the analytical status of research hypotheses. They are as follows: (1) the hypothesis of late articulation of individual liberal rights; (2) the hypothesis of aversion to cities, inscribed in the elite's ways of thinking; (3) the hypothesis of the ambiguous social status of the bourgeoisie; (4) the hypothesis of the dialectical weakness of the relationship between the bourgeoisie and the common people.

The last 120 years will be subject to a separate reflection. This period is most often analysed in the context of the evolution of the 'right to the city.' In this paper, based on different analysis, we identify five factors that make the Polish experiences of class self-organization different, according to the editor of the volume:

(i) the first factor: a 'shadow' of the national issue, referring directly to the specificity of the nation-building process (as a consequence of the collapse of the states of the region, subordinated to the regional hegemonies, Wandycz 1993) that took place in this part of Europe. It reflected in the case of Poland deeper conditions related to the model of power shaped under the influence of the republican ethos of the 'republic of the noble' from the late Middle Ages and the Renaissance. This influenced the social status of the common people, resulting directly from political decisions maintaining the so-called secondary serfdom of the peasants up to the 19th century, as well as the weakness of people's rebellions in the lands of the First Republic of Poland which, in turn, directly impacted on the dynamics of urban development;

(ii) the second factor: the curse of starting over, concerning the consequences of very profound population changes that took place in Central Europe over the 20th century. In this particular variant of Polish destiny analysed here it meant, for example, an almost complete exchange of urban populations, population losses in the context of the extermination and warfare victims in the World War II and also substantial waves of resettlements that followed the post-war political decisions; 
(iii) the third factor: the progressive republicanism of 'Solidarity' shows that the specificity of the impact of individual historical phenomena, such as the emergence of a mass social movement that imposes narratives and dominates public discourse, can change the course of history. This very rare occurrence has become an axiological and 'instrumental' point of reference for later phenomena of self-organization, shaping the ways of thinking about activism, its meaning and the framework for undertaken activities;

(iv) the fourth factor: the radical anarchist alternative without capitalism illustrates another phenomenon no longer on the scale of the state community but on the scale of specific cities like the Tri-City (Trójmiasto) where, under the real socialism terms, a utopian vision of radical urban democracy was being built since 1983. This concept, later incorporated into the anarchist and neo-anarchist perspective, became the basis for generating a tradition that, several decades later, became a counterpoint to the Congress of Urban Movements in Poland;

(v) the fifth factor: the meliorative trend of 'concrete narrative' indicates the limitations inherent in the concepts of local self-organization and the broadening interpretation of the 'right to the city' in the conditions of the umbrella structures of urban movements. The broad formula, combining very different positions and ideological tones, requires the use of a set of silent assumptions that allow the implementation of a certain range of obvious goals (most often inspired by experiences from outside the home towns) but at the same time are not able to propose a coherent, original overlook that would serve the 'universalisation' of social movement and would allow it a certain range of autonomous expression.

Analysing the factors differentiating the specificity of the 'right to the city' drawn from the scientific discourse in relation to the Polish experience, one comes to the conclusion that the way of perceiving social self-organization is the result of a cumulative process. A process that can be described as a continuity, even if there are clear turning points and strong interactions between successive historical 'contingencies' imposed in it. Moreover, this image fits in a way into a cause-and-effect pattern, parallel to the dominant approaches. A template that, without the initial elements of specific 'remnants' (such as the motive of state sovereignty or aversion to cities) and their 'derivatives,' cannot be entirely clear. To some extent, this indicates the autonomy of reflection on the local scale which probably does not facilitate its integration with knowledge frames from other scales: regional and universal European.

\section{MEETING OF THE WATERS - EUROPEAN SCALE}

It would seem that the most primary research concept, historically conceptualizing urban activism, is the 'right to the city.' (Engels 1969; Lefebvre 1996; Harvey 2008; Pluciński 2012) It is related to the concept that can be anchored in the articulation of the class social movement and the emancipating social movement in the cities under 
capitalism, mainly amongst the working class, that used urban space as field or sometimes subject of their activity. In other words, in reference to Lefebvre's position: "its goal was to search for and extract the suppressed potentiality of the city, following the tradition of intellectual and practical resistance to instrumentalised capitalist relations.” (Pluciński 2012: 104) This attitude allows finding basic connections between the meaning of 'right to the city' and the concept of 'social self-organization' oriented, however, at specific class positions. At the same time, the aforementioned class movement seems to legitimately refer not only to workers but more broadly to the perspective of 'people's interests' (more precisely: the articulated claim of the people to participate in the management of the urban community). The reference to the 'people' allows the cognitive perspective to be broadened to include other class positions and, in a way, modernises the historical approach known from Frederick Engels' works. Wiktor Marzec, describing the process of social emancipation and self-organization at the turn of the 20th century in Central Europe, starts his reflection by presenting the specificity of the pre-political reality of the masses that

did have historical subjectivity also when they simply aroused fear. At that time, the process of political communication that would change both sides had not yet been started. Domination was ensured by excluding the 'mob' from outside the political community of thinking people. The plebeians were deprived of the legitimacy based on the elementary equality of human beings. A plebeian claim could not be articulated as a political voice, a discourse attesting to being spoken by thinking people. In the eyes of the mighty, it was not a political voice, but a noise, an animal sound of misfortune and sufferance, but not a discursive expression of thought. (Marzec 2016: 16)

Thus, 'the interests of the common people' gained an understandable meaning only as a consequence of the social process. This was primarily done by means of 'communication by action,' (Nowak 2015) understood as a form of emotional reaction (rebellion) to specific economic, political or environmental contingencies which, as a result, changed all sides of the social conflict. Such an approach indicates the action-oriented, radical and often extra-linguistic nature of articulating the plebeian 'right to the city.' Margit Mayer, referring to the contemporary perspective, prescinds from the form of protest (whether it is a presence, a voice or an action in space) and points out the significance of "moral claim founded on fundamental principles of justice, of ethics, of virtue, of the good - not as a legal claim enforceable through a judicial process today." (Mayer 2009: 367) Referring to Lefebvre, ">the right to the city< is less a juridical right, but rather an oppositional demand, which challenges the claims of the rich and powerful." (Mayer 2009: 367) Lefebvre plays an important role here, offering a different approach in comparison to the economic vision of the city attributed to Castells in his publication from the early 1970s. Let us add that, as Mark Purcell suggests:

Lefebvre does not see the right to the city as an incremental addition to existing liberal-democratic rights. He sees it as an essential element of a wider political struggle for revolution. (Purcell 2013: 142) 
Importantly, in the adopted understanding, the "right to the city" includes not only a potential for class resistance - and therefore for assumptions proper to Marxist-Engels orthodoxy (Purcell 2013: 145), but also an opportunity for grassroots self-organisation, the sources of which lie in the understanding of justice and not necessarily only in a redistributive way. This way of thinking about the right to the city is well commented by Mayer in the reference to the 2008 crisis, treated as:

the window of opportunity for the Lefebvrian right to the city demand, which is not about inclusion in a structurally unequal and exploitative system, but about democratizing cities and their decision-making processes. (Mayer 2009: 371)

Thus, it is a chance to complete formal recognition of marginalised groups with real self-organization and co-decision, contesting the existing regime founded on the economic domination of the holders. Therefore, the right to the city remains under a certain tension both in relation to classical Marxism (with its focus on the economy and the universal class context) ${ }^{2}$ and with regard to the merely formal and functional recognition of individual rights as well as the equality of individuals, which is usually attributed to the philosophical sources of the Enlightenment and furthermore the legal norms of modernity or directly to liberal ideology. The shape of this ideology is perfectly internalised by the middle segments of the modern societies structure, the interests of which, at least on the doctrine level, this ideology defends. Mark Purcell describes the peculiarities of this thinking in relation to economic values and the conservative concept of freedom:

they protect it by establishing a strong distinction between the public and private spheres, and by granting individuals numerous rights designed to prevent limitations to their liberty either by fellow citizens or by the state. In this political imagination, rights are enduring legal protections that are granted to individual citizens by the liberal-democratic state. (Purcell 2013: 142)

This tension, conventionally illustrated by the axis: common people - middle and upper segments of the social structure, can also be exemplified by the opposition of the postulates the access to the catalogue of resources or rights (example: World Charter for the Human Right to the City, but also many other documents created at the international level and at the level of individual cities [Purcell 2013: 143-145]) and demands for real (co)-management present in the anarchist and neo-anarchist tradition. It is worth emphasizing that this division, visible in the basis of Lefebvre's concept as interpreted by Mayer and Purcell, maintains to some extent its relevance in the perspective of Central Europe with its cultural and social specificity. However, there are separate ways leading to this coincidence/consistency that are worth at least being looked at. Przemysław Pluciński illustrates it suggestively in this volume, using the metaphor 'the meeting of the waters.' (Pluciński 2020)

\footnotetext{
${ }^{2}$ Purcell describes Lefebvre's position pointing out that "we can read Lefebvre's attention to space and the urban as a way to break open the limits of an economistic approach, to theorize actors beyond class actors, political sites beyond the workplace (cf. Lefebvre 1991/1974: 386), and historical forces beyond economic production.” (Purcell 2013: 145)
} 


\section{HISTORICAL BASES FOR DIFFERENTIATING THE 'RIGHT TO THE CITY.' THE CENTRAL EUROPE SCALE}

It seems that the change in the scale of description changes its content quite significantly. Needless to say, the choice of the research paradigm is the essential corollary to defined criteria used by the researcher. In the adopted perspective, at the Central Europe level of analysis, we will study the perspective of political decisions and events (conflicts, wars), taking into account positions which are less known in the field of urban studies, positions analysing development processes from the historical sociology or historical-comparative sociology perspectives. (Brzechczyn 2020) Obviously, the very choice of 'historiosophy' requires an explanation. What seems decisive here is the conviction that the scope of the phenomena divergence, that will be discussed later, is relevant for the attempts to explain the phenomena of contestation, especially to explain references to the importance of culture and long-term social processes. ${ }^{3}$ In this context, in sociological studies we often use terms that have the status of meta-narrative, 'social modernisation,' or we point out universal emancipation tendencies. In a sense, in Central Europe, these meta-narratives play a more significant role, so much so that Central Europe itself is sometimes perceived as an element of the analytical context used to describe, for example, the process of systemic transformation proving the ultimate domination of capitalism over socialism, democracy over authoritarianism or pointing out the behaviour of emancipation processes as factors defining the dynamics of social movements. The proposed analysis is not finalistic, unlike the proposal of Francis Fukuyama (1992), and the processes of social change are conditioned by many factors, approached differently by particular concepts that also indicate specific patterns of impact: 'paths' (Stark 1992) or 'cascades.' (Brzechczyn 2020) It results from the belief that the use of a universal, one (linear and deterministic) scheme of inference about the dynamics of social self-organization can be negotiable. This does not mean that different stories modify the dominant pattern of social change, but only that they introduce a conditional mode into the study. Therefore, instead of analysing relationships, it is worth to consider coincidences and systemic dependencies or exogamous relationships (analysed, for example, in the postcolonial perspective language: Zarycki 2005, Costa 2007, Owczarzak 2009, Mayblin, Piekut, \& Valentine 2016, Zarycki 2016).

From the point of view of the idealisation strategy, crucial for our perspective, (and the concretisation that follows it), the 'core' factors that differentiate or even modify the entire social process in various geographical areas are particularly interesting. Krzysztof Brzechczyn, describing the core historical premise of the European duality (in the context of its long duration), writes:

The process was accompanied by growth in obligations imposed by the lords over the peasantry, and by the introduction of the so-called second serfdom. Ad-

\footnotetext{
${ }^{3}$ However, this list may be longer: we can mention here influences of the dominant ideology (that we find hard to avoid in practice), such as neoliberalism, diachronic changes of the tools used by social movements, their goals as elements of the social process, and some sort of framework for meta-narratives.
} 
ditionally, the economic domination of the nobility was strengthened in political life - in all Central European societies, burghers exerted an insubstantial impact on public life as compared to Western Europe, whereas the state was subordinated to the interests of the nobility. (Brzechczyn 2019: 6)

Robert Brenner, whose work is also referred to by Brzechczyn, indicates the theme of interdependence or feedback, traces of which can already be found in Adam Smith's work. (Smith 2007: 10) Robert Brenner describes them as follows:

the case of Eastern Europe, where during the late medieval and early modern period the powerful impact of the world market for grain gave a major impetus to the tightening of peasant bondage at the same time as it was stimulating the development of capitalism in the West. (Brenner 1976: 43)

The premises of duality mentioned by this researcher become an element of the description of the dynamics of capitalistic development and, more precisely, growing differences in its centre. These differences are:

(I) the decline versus the persistence of serfdom and its effects; (2) the emergence and predominance of secure small peasant property versus the rise of landlord-large tenant farmer relations on the land. (Brenner 1976: 47)

Of course, historically speaking more similar factors and complex interdependencies can be found, some of them supporting the tendency to increase differences over time. ${ }^{4}$ What is crucial here is the fact that social phenomena, including manifestations of contestation, may have their own dynamics (or lack thereof), which results in determining another configuration of influencing factors (some would call them secondary) that had a chance to play a role in a specific context. (Topolski 1996; Małowist 2006; Sosnowska 2018; Brzechczyn 2020) These conditions will be a little more understandable when the interpretations indicate specific consequences which, in the author's opinion, it is difficult to disregard. These will be, for example:

- relative weakness of the cities, related to peasant serfdom, and the resulting weakness of the bourgeoisie as a social state (which applies to Poland and Hungary, but less to the Czech Republic) and as the origin of the middle class in the 20th century;

- nation-creating phenomena in the absence of statehood (typical of the region in the 19th century);

- the significant migratory movements that started the numerous and influential diasporas in the USA and Latin America, but also in the countries that dominated central Europe before they regained independence as a consequence of World War I;

\footnotetext{
${ }^{4}$ Such concept was also present in the institutionalists research from the 1990s (North 1990), in the sociological studies (Wallerstein 1992), but also in studies of the present when we ask ourselves "why"? It is the basis for understanding the evolution of societies, whether in accordance with cultural imaginaries, or with perspectives that are sometimes described as macro-social.
} 
- forms of self-organization based on community and social class: we can give as an example the revisionist contestation of real socialism related to the emergence of the so-called the democratic opposition in the late 1960s in Central Europe, recruited from people whose cultural origin can be attributed to the Central European intelligentsia (classes with very particular regional specificity, non-existent elsewhere, Chałasiński \& Szczepański 1962, Zarycki 2009);

- contemporary processes of states' (de)composition: the collapse of the Soviet Union, the division of Czechoslovakia, the collapse of Yugoslavia or the reunification of Germany (through the incorporation of the DDR);

- different ways of departing from the so-called real socialism, based on more or less radical co-modification strategies (Hamilton, Dimitrovska Andrews, Pichler-Milanovi 2005);

- remnants of real socialism that can also be treated as a differentiating factor (Segert 3013);

- different consequences and different strategies of reaction to the economic crisis of 2008 (Dijkstra, Garcilazo, \& McCann 2015);

- references to the contemporary phenomenon of populism. (Muler 2017; Lovec 2019)

\section{LONGUE DURÉE - HISTORICAL CONDITIONS. THE SCALE OF ONE SOCIETY}

We find yet another depiction of the factors describing this phenomenon when the subject of analysis is a specific society with its historical and cultural particularities. In the case of Poland, one needs to go back relatively far into the past, to the late Middle Ages. In this context, the origin of the 'right to the city' movements is part of the discussion about the so-called noble democracy and the systemic status of the nobility in the 17 th and 18 th centuries. This approach is justified by the complexity of the emergence of class subjectivity and, more precisely, by the public absence of the peasants and the marginal presence of the bourgeoisie in this area. Reaching back to the 19th century, as it is usually done in relation to the works of Karl Marx or more precisely to the works of Frederick Engels in relation to the city (Pluciński 2012), is in this case unjustified as it is generally impossible to consider the question of class subjectivity throughout the 19th century (in the accepted meaning of the right to a city) in cities in this part of Europe. Firstly, this situation is due to the outcome of civil rights that, in the lands between imperial Prussia and Russia, were inscribed in the colonial context caused by the loss of state sovereignty by the First Republic of Poland (at the end of the 18th century). Secondly, it derived from a specific regional variant that shaped social relations blocking the development of cities as autonomous centres on the economic, social and awareness levels.

(1) This remark suggests that the liberal concept of citizenship was unknown and 
seriously limited for a relatively long time, at least if we assume that the basis for the meaning of this concept is the acceptance (recognition) of universal negative rights of all, as defined by Thomas H. Marshall in his concept of civil citizenship. (Marshall 1950) The situation changed under the influence of the evolution of absolutist partitioning states that had long been the periphery of Europe; it also changed in line with the emancipatory trends in metropolises. In the case of the area of Central Europe occupied by the Russian Empire, the change took place after yet another national-liberation uprising of the sympathizers of the First Republic of Poland (1863); as a result, the tsar decided to abandon the anachronistic second serfdom model. ${ }^{5}$

At this point, it is necessary to evoke one of the widespread explanations of the specificity of the Polish cultural contestation (to a significant extent national and liberating) in the later historical period. It is attributed to the strength of the patriarchal nobility culture or, a little more symbolically, to the archetype of the 'noble manor' - the abode of an extended noble family, considered as the axiological centre of the community $^{6}$ - in opposition to the tenement house or the agonistic form of the market square in the city space. The status of the nobility requires a few words of clarification below, due to their attitude to cities.

(2) Our review here is that the nobility's ambivalent attitude towards urban life (also present in the following post-noble ages) was one of the major elements of the 17th-century noble elite's cultural specificity, referring to the knighthood ethos of the First Republic of Poland. As Maria Bogucka says:

Old Polish aversion to cities arose for two kinds of reasons: aesthetic and ethical. The living conditions in an early-modern city: crowded, cramped, narrow space, dirt and stench everywhere, all of this was a daunting and abhorring perspective for a nobleman who was used to living close to nature, among vast fields, in clean air, filled with the smell of meadows and forests. The nobility regarded with reluctance staying in cities longer than strictly necessary. (Bogucka 2009: 10)

This phenomenon of cultural distance towards the city and, what is equally important, the durability of its influence can be explained by: 1) the dynamics of political decisions in the First Republic of Poland and the acquisition of political domination in the form of noble democracy (the so-called golden freedom) in the 16th century; 2) by the economic atrophy of the state that followed. In the literature on the subject appears the concept of 'Sarmacy' (Maciejewski 1974; Orzeł 2010; Niedźwiedź 2015), although less frequently in the historical sociology studies. This concept holds a somewhat blurred meaning and can be interpreted as lifestyle, ideology or a kind of self-identification. Nevertheless, it indicates cultural attractiveness of the vision of the Commonwealth of many nations and the attractiveness of the nobility's position as beneficiaries of the First Republic's model of power. To quote Janusz Maciejewski

\footnotetext{
${ }^{5}$ They insurrectionists gained a range of negative freedom. Importantly, this emancipatory gesture was not so much aimed at modernizing social relations as at undermining the direct and indirect dependence of the peasants on the local noble elites involved in the uprising.

${ }^{6}$ Which for a relatively long time, and in the architectural context even today, has marked the imagination of the Polish middle class.
} 
from the 1970s:

the Sarmatian nobility was deeply convinced that they were an exception, an island of freedom in a sea of despotism (which they were very proud of). This view has remained a common belief to this day, even among historians. (Maciejewski 1974: 22)

The impoverishment of the nobility, initiated under the influence of the development of capitalism (in the 18th and 19th centuries), but also the aftermath of successive national-liberation uprisings (1830-31, 1863-64), launched the process of creating a specific social layer: intelligentsia, while maintaining the social status of the noble elite. It should be noted that:

the intelligentsia consisted of elements from the manor and from the serfdom farm. The shaping of the Polish intelligentsia is inseparable on the one hand with the history of the fall of the farm and the manor house, and on the other hand with the history of the development of cities and industry, urbanisation and industrialisation. Polish intelligentsia is a product - unfortunately [...] it is a by-product of the transformation of pre-capitalist noble, agricultural and rural Poland, based on a countryside manor and serfdom farms, into a capitalist, urban and industrial country. (Chałasiński 2020: 2)

Also:

The core of the urban intelligentsia that determined its social and spiritual aspect was not created through social advancement of the emancipating masses of the people, but through migrants from the countryside manor and the serf farm. (Chałasiński 2020: 5)

As a result, a cultural model of the elite strongly encouraging freedom, tradition and the agrarian community were shaped. It referred to the image of a sovereign, multi-ethnic state and drew attention to the problem of regaining state independence. In other words: it referred to the petrification of the traditional vision of social structure, in opposition to the Marschall research regarding political citizenship, at least until the beginning of the 20th century and the turning point marked by the 20th-century revolutions.

(3) One can risk another generalisation: that the loss of the state independence of the First Republic, which was a failure of the systemic project unique in Europe at that time: democracy of the mighty ('noble's democracy'), created a traumatic experience. Citizens lost their 'paradise,' which generated a permanent axis of a dispute of a sentimental nature. The 'paradise' consisted of a multicultural city, space not entirely 'homely,' whereas its inhabitants: townsmen, bourgeois were perceived ambiguously in public life. Let us add that the axis of social division did not have a class character (in the Marxist sense of this category), but rather referred to divisions into what is familiar and what is foreign (in relation to specific groups or classes) and pointed out the premises of state and functional differentiation that did not define the world in terms of conflict. At the same time, these categories limited the problem of recognition (using the contemporary concept) to the whole community with the deep ine- 
qualities that it contained and the characteristic paternalism of upper-class towards the commoners.

It is also not a coincidence that the genetic description includes the issue of ethnic affiliation (referred to in the context of the description of the bourgeoisie status, distant from the vision of the 'Sarmatian' state community) because, probably paradoxically, the ethnically dominant representatives of the nations co-creating the First Republic (Poles, Lithuanians and Ruthenians) did not constitute the majority of the city inhabitants (cities which were co-created by numerous minorities, including to a large extent the German and Jewish minorities) and the proportions of the population changed over time, not necessarily in favour of the ethnic domination of Poles. It seems that this had significant consequences for urban social dynamics.

In a way, the bourgeoisie never acquired the status of 'governor of souls' in the lands of the First Republic (hegemon, to use Gramsci's concept, understood as "a form of intellectual and moral leadership in general” - Riley 2011), which can be considered as a distinctive feature of cultural specificity, influencing the evolution of cities in this part of Europe in the 19th and 20th centuries. ${ }^{7}$ One of the consequences of the aversion to urban life was also an ambivalent attitude towards the market economy. This economy, based on the specialised work, trade and accumulation as described by Weber in The Protestant Ethic and the Spirit of Capitalism, marked the birth of the modern bourgeois class. Interestingly, in the texts from that period, there was also an ethical aspect that usually accompanied the emergence of stereotypes and prejudices toward city inhabitants. As Bogucka emphasizes: "it was a widespread and growing belief that every townsperson was an enemy and a scammer, a speculating parasite ruining the country." (Bogucka 2009: 11) Of course, it is difficult to estimate the durability of this perception but its influence, including inclinations to a certain separateness, undoubtedly impacted on building tension between the vision of the state of the First Republic and the city, the latter being perceived as a kind of 'necessary evil' one tries to escape from whenever it is possible. ${ }^{8}$ Historically, even in the period of the First Republic of Poland, the image of Gdańsk (17th century) was particularly ambivalent as a place where grain, an important export commodity of Polish lands, was exported. Attribution of monopolistic practices and non-compliance to the law was a source of constant disputes between the Crown and the city regarding the status of local government. Later, the city of Warsaw, rising to the level of a metropolis, became the subject of resentments undermining the status of the 'golden noble freedom.' Bogucka writes: "in the eyes of the provincial nobility and conservative magnates [Warsaw became - M.N.] the incarnation of all evil, the embodiment of forces allegedly striving to introduce absolutum dominium in the noble Republic and erase freedom of

\footnotetext{
${ }^{7}$ This influence was due to factors related to the variable dynamics of migration, ethnic diversity, self-identity problems related to living in a city and city life as well as multilingualism and communication problems of city residents.

${ }^{8}$ This specificity can also be observed nowadays within the emerging middle class in this part of Europe in the modern sub-urbanisation dynamics occurring despite the efforts of municipal authorities, sometimes even evoking an image of the exodus to the countryside, along with the progressive improvement of middle class' material situation.
} 
'highborns." (Bogucka 2009: 12) This does not mean that the lands of the First Republic were subject to different development trends in the 15th century than other areas of Europe, but it means that the process of progressive urbanisation (an increase in the number of urban centres) and the demographic development of the largest cities was marked by an ambivalent attitude of the culturally and politically dominant noble elites (we already mentioned the concept of sarmatia), an attitude that became more pronounced along with the political state crisis, right until its total collapse. Its traces can be analysed by juxtaposing two models of urban development: polycentric and monocentric, as well as the notion of 'centrality,' which is key to Walter Christaller's concept (the completeness of the role of supplier and consumer of goods and services, Nowosielska 1992: 9; Bogucka 2009: 16). The former was typical of autocracy with a clearly defined centre of power (widespread in Western Europe); the latter reflected better the decentralised First Republic's model of power, where the position of the nobility and the need to build many administration and service centres shaped the image of urbanisation dominated by small, although relatively numerous, urban centres with limited autonomy, interconnected in a way that evokes a network.

(4) As a result, the bourgeoisie, considered as a reference group (Bogucka 2009: 10) and as an outpost of capitalist relations, was less attractive. The weak voice of the 'people' in the Polish historical narrative (few personal documents) was similarly symptomatic; this situation can be attributed to their lower position, but it was rather the way of seeing social reality dominated by the traditional image of functional dependence and subordination. We can propose at this point our third general these. Using the Marxist optics, the weaker townspeople and the bourgeoisie deriving partly from it (partly, because the bourgeois class was also created by the nobility, impoverished and deprived of wealth) created less effectively their alter ego in the form of an organised working class (which, probably longer than anywhere else, was culturally influenced by state relations inherited from the past). It is a widespread belief among researchers of the subject that the weakness of class revolts forms a distinctive factor in Poland; this conviction may have significant consequences for the analysis of contemporary manifestations of social dynamics. The key issue of spatial mobility was thus marked by barriers created by the First Republic culture and the consequences of the state's political collapse. Therefore, the phenomenon of escaping the idiocy of countryside life' (a paraphrase taken from the Communist Party manifesto) and then migrations from the countryside to the cities, took on the attributes of postponed urban socialisation of the people. Following this reasoning, in the Central European variant, it is probably more legitimate to write about the postulates of 'the right to the countryside' (and not the 'right to the city') as emancipation claims and factors of social change. However, this emancipation process was never completed to a degree that would justify a historiosophical correction of the concept, the source of which can be attributed to Engels. (Kuligowski 2015: 70)

The process of urban 'socialisation' of countryside migrants was tentative and, in the absence of other analysis, we will refer here to a work examining the reality of the turn of the 19th and 20th centuries. According to William Thomas and Florian Znaniecki, (Thomas \& Znaniecki 1958) the process went from the atrophy of tradi- 
tional (neighbourly, family) ties towards integration within new life conditions. As it seems, in the local conditions of Central European cities, both concepts would also have their application, making up the specificity of building an urban society from below, without a clear social and axiological point of reference that urban patriciate, autonomous in the political sense, used to be elsewhere. If the proposed course of reasoning and cultural argumentation has a chance to defend itself, the model of urban development in this part of Europe has to gain a certain distinctiveness, the consequences of which can be followed by pointing out the importance of the state context, attitudes of the elites, ethnic diversity and relations that come from outside the perception of the (autonomous) city as an independent vehicle for modernisation. Obviously, such a conclusion encounters certain limitations and it is more appropriate to write not about the multi-linearity of the 'right to the city' development, but about the extension of the evolution towards modern relations, which had its original milestones in Central Europe, milestones related to the consequences of the state subjectivity loss. These milestones might be, in the areas dominated by the tradition of the First Republic, subsequent national liberation uprisings (which the 'people' knew about and often distanced themselves from) and workers' riots directed not only against factory owners but against local administration that, inevitably, starting from the 19th century was an administration that was culturally more foreign.

Nevertheless, it is worth noting that the phenomena of urban revolts, although not spectacular in numbers, accompanied the fall of the First Republic of Poland. We can find an example of this circumstance in the "spontaneous rebellion in Rehan's cloth factory in 1794 where - apart from paid workers - prisoners were also employed." (Kuligowski 2015: 71) We can also mention strikes preceding the January Uprising (1824-27) in Zgierz, Aleksandrów, Tomaszów, Łódź and Turek or gatherings that took place in Wielkopolska during the Spring of Nations. "On April 28 1847, due to poor harvest, hunger riots broke out in Poznań. 140 unemployed people demanded jobs from the local authorities. On April 30 1847, armed clashes took place in Chwaliszewo and Trzemeszno." (Kuligowski 2005: 71) Similarly, on the eve of the next insurrection, there were workers' riots as well, as Kuligowski writes: “workers from Łódź were in the lead of the social struggles of that time. As a result of the April 1861 rebellion of the so-called machine destroyers, the two-headed tsarist eagle was thrown from the town hall and patriotic songs were sung." (Kuligowski 2015: 72) The beginning of the 20th century is probably when the key events that mark the claims of the masses in terms of identity occurred.

It is no coincidence that the history of the 1905 revolution in Poland occupies an important place in the description of the dynamics of articulation of the theoretical 'right to the city.' Wiktor Marzec, in the introduction to his book on revolutionary events, states:

The sense that the world 'has gone out of shape' was more and more common in the years of economic crisis, increased conscription to the army and growing national problems on the outskirts of the tsarist state. Initially, it was not specified, it had no specific means of expression. For the workers and the intelligentsia 
party members the moment when, in January 1905, the Kingdom of Poland was embraced by massive, if not general, strikes was therefore a surprise. Something 'was floating in the air.' Workers and peasants began to feel that their situation might be different, that perhaps the world they knew was not the only form of life they deserved as human beings. The next day, even if it was still the same as the present day, would be the result of the battle. (Marzec 2016:13)

The main training ground for this emancipation movement development was the 'young' city that experienced an extraordinary demographic boom over the course of around 100 years, emerging from a small village and taking advantage of the growing demand for light industry products in the Russian metropolis.

\section{DIFFERENTIATING FACTORS - CONTEMPORARY PERSPECTIVE}

It seems useful to approach the issue of the contemporary specificity of the Polish 'right to the city' in a manner similar to the description of 'historical' conditions, with the difference that in the case of the latest historical events it is reasonable to refer to selected documents, including specific activists' statements, statistics and sociographic studies and the surprisingly poorly analysed 'Program of NSZZ Solidarność' from 1981. Such analysis allows for the reconstruction of specific conditions in terms of factors differentiating the process of constructing the 'right to the city' in a contemporary perspective. As an introduction, we will recall historical data from the beginning of the 20th century and demographic data about Łódź, today a 700,000 metropolis falling into a de-industrial crisis. While we do realise that other examples are also available, let this date be used as a real case study.

\section{THE FIRST FACTOR: THE 'SHADOW’ OF THE NATIONAL ISSUE ON THE EXAMPLE OF ŁÓDŹ HISTORY}

Łódź is a city which growing dynamics was comparable, for example, to the American Chicago in the same period of time (during the 19 th century).${ }^{9}$ In the first period of industrialisation, recruitment for the emerging craft plants was based on the population of towns and cities. Along with the expansion of manufactories, an increasing share was gained by peasants, whose availability to employers was increased by the policy

\footnotetext{
${ }^{9}$ It is interesting to compare both cases, mainly due to the dynamics of urban formation and parallels related to the first half of the nineteenth century. In the case of Łódź in 1820, based on regulation signed by prince governor Józef Zajączek, the government of the Kingdom of Poland recognized Łódź as an industrial settlement within Kalisz-Masovian industrial district and assigned its role as a weaving centre. Based on data from 1830, Łódź was inhabited by 539 weaving families; in 1914, i.e. after 84 years, the city already had 500,000. residents (based on: Łódź 1820-1914 - city and its inhabitants, online document: https://histmag.org/Lodz-1820-1914-miasto-i-jego-mieszkancy-11187, Winter 2019). Chicago was incorporated as a town in 1833 and became a city in 1837, which launched investments related to connecting the telegraph and railway line. In 1910, after about 80 years, it reached 2.2 million inhabitants (based on: on-line material: Chicago, https://www.history.com/topics/us-states/chicago, Winter 2019). Although the intensity of the increase in the number of Chicago residents was about 4 times higher than Łódź, development logistics in both cities seem to be part of a similar process.
} 
of the Russian administration aimed at weakening the social and economic position of the nobility and the lower-class landlords, thus forcing social mobility caused by the deteriorating material situation.

The first workers' demonstrations that can be attributed to the dynamics of the 'right to the city' occurred at the end of the 19th century (1892) when the instruments of protests and workers' contestation began to take shape. (Marzec 2016) In a sense, the 'right to the city' notion of that time can be seen as the primary right to be visible - to proclaim slogans in public, and therefore to an expressive (in opposition to discursive) presence in public space. ${ }^{10}$ The dynamics of the development of capitalism, more precisely tensions related to working and social conditions at the beginning of the 20th century, led to further protests against employers and confrontations with the Russian administration. Marzec reconstructs the events of the budding revolution in this manner: "The first clashes with the police and the army took place in Warsaw in the fall of 1904. Accumulated discontent erupted in January 1905 . Influenced by the news of 'Bloody Sunday' (a brutal pacification of a peaceful demonstration against the Tsar) in St. Petersburg, a mass strike broke out in Łódź." (Marzec 2016) The January strike revealed some aspects of the fight for the 'right to the city' - forcing workshops and manufactories to participate in a strike and taking over semi-public spaces, e.g. asking the public to leave cafes and theatres. In a way, these events were acts of protest revealing the expectation of recognition, a development of the instruments of rebellion known from earlier speeches which, by the way, did not cause social resistance. In June, riots broke out in Łódź, barricades were erected. These events were a direct, somewhat provoked, spontaneous reaction to the army's attack on workers' demonstrations. The proceedings of the first half of 1905 were a prelude to long-lasting workers' demonstrations (1905-07), disorganized at first, then increasingly becoming a form of a fight for specific goals of popular political parties, with different ideological colours. (Piskała \& Marzec 2013; Marzec 2016)

It is worth mentioning here the progressive differentiation of the workers' self-organisation environment where three currents competed with each other: Social Democracy of the Kingdom of Poland and Lithuania (SDKPiL), offering a class program "exceeding and even invalidating national identification"; Polish Socialist Party (PPS) linking the vision of socialism with the people's involvement in the cause of regaining independence, and the conservative National Workers' Union (NZR) referring to the concept of the nation. (Marzec 2016) Differences in positions regarding the need to fight for independence and the forms of this warfare (e.g. using terrorism) formed the axis of dispute, which in the case of the PPS (divided early into the so-called 'young' and 'old' ones) led to a deep separation in the following decades, influencing the shape

\footnotetext{
${ }^{10}$ Let us add that this particular event ended with pacification and the speaker's detention. The process of self-organisation and building the political awareness of the workers progressed, but faced basic problems related to the low level of enrolment rate. Leaflets and brochures published at the beginning of the 20th century illustrated the scope of the challenges faced by the workers. The content of these documents became the main material analysed in the above-mentioned work by Wiktor Marzec (2015). Their content can also be found in the published 'Political Critique Guide' entitled Rewolucja 1905. (Piskała \& Marzec 2013)
} 
of Polish left-wing parties even when Poland regained state independence in 1918. (Piskała 2013)

What seems to be important for the next changes within workers' self-organisation structures, is that they are the consequence of the revolutionary events and implementation of specific demands and changes forced on the Tsar aimed, among others, at extending the electoral law to workers and peasants. In practice, however, they were not accompanied by an increase in the political subjectivity of the working class. Thus, the post-revolutionary changes did not turn out to be deep and permanent (especially when analysed in terms of class emancipation or class consciousness). ${ }^{11}$ However, they triggered the process of empowerment and laid the foundations for the development of urban self-organisation that we know from liberal societies. We can summarise this process by saying that:

it was of great importance for the formation of the seeds of civil society, the practical learning of self-governance and cooperation. These experiences turned out to be extremely important when, in 1918, it was time to rebuild an independent state. It is also difficult to overestimate the importance of the long-term effects of the activities of many educational and cultural institutions established at that time. (Piskała 2013: 43)

At the same time, we can postulate the extinction of class forms of contestation which is not only a consequence of the repressions on the part of the Russian Empire administration (which was regaining control over the revolted cities precisely through these repressions), but also the formation of the expression of subjectivity. In the case of Poland, the victorious option (a derivative of the 'nobility topos') was: regaining state subjectivity. Nowadays, we would call it right-wing, as it places at the centre the traditional community identity with its 'functional' ethnic diversity. The consequences of this fact are crucial for the history of the reborn Polish state as an ethnically diverse state with a strong role of state nationalism. It is worth emphasizing that the workers' demonstrations were a response to outside events, ${ }^{12}$ more precisely they were an eruption of discontent towards the authoritarian system on the periphery of the Empire, ${ }^{13}$ during which revisionist tendencies prevailed. In a way, they were in

\footnotetext{
${ }^{11}$ However, as Piskała points out, "In the course of several revolutionary months, the political empowerment of the people took place on an unbelievable scale. The way that led to this was a spontaneous rebellion, not a top-down, previously planned reform.” (Piskała 2013)

${ }^{12}$ The inspiration for the uprising, later called the Łódź Uprising or the Revolution of 1905, was the aftermath of the economic crisis in the Russian Empire and a direct consequence of the political crisis related to Russia's defeat in the war with Japan. The anti-war and social protests covered industrial centres in Russia and, in this sense, the events in Łódź were part of a wider movement of Tsar's progressive delegitimisation. For the Polish lands, however, they had a special meaning precisely because of their popular and 'formative' character.

${ }^{13}$ Moreover, this peripherality introduces original threads to the story of the becoming of class subjectivity in Poland. As Robert Blobaum notes: "The revolutionary processes in Poland in 1905 were in many respects much more advanced and radical than in Russia itself. I found the dynamics of the revolution extremely interesting, much more interesting than in the case of St. Petersburg or Moscow. So I started with an analysis of the Russian perspective, and then in my research on the social democratic
} 
competition with social or class postulates formulated in the metropolis. The pressure aimed at regaining the political subjectivity of societies and, consequently, state subjectivity, was a widespread phenomenon in Central Europe; it could result from its peripheral position in relation to the centre of the continent and the dramatic political consequences of World War I. This 'peripherality,' as opposed to the metropolis, was of significant importance both for the course of events and for the social and political consequences of events in this part of Europe. Undoubtedly, it also defined the way of understanding and valuing the 'right to the city.'

The critical test of the evolution of the mass consciousness among the inhabitants of the lands of the former Polish Republic was the universal commitment to defend the newly regained state sovereignty in 1918. The young state was defended against the Soviet troops in the 1920 War, ${ }^{14}$ despite the indisputable presence of the pressure of internationalist movements workers directed against the Second Republic of Poland (as a national and nationalist state). The mobilisation occurred in a very short time and on a mass scale as the value of maintaining independence turned out to be more important. As it seems, the aforementioned situation lasted at least until the end of World War II. However, the tragic consequences of the latter forced another radical re-evaluation, this time towards communism and the so-called 'real socialism' in Central Europe. Again, the causative factor was the external context and the result was a second peripheralisation.

\section{THE SECOND FACTOR: 'THE CURSE OF STARTING OVER'}

The consequences of intense political and social changes, apart from the catalogue of other modifications, strengthened the urbanisation of Polish society. It is worth emphasizing that this phenomenon happened even if the Polish people in the 19th century did not constitute the overwhelming majority in the cities of the First Republic of Poland. ${ }^{15}$ The consequences of the extermination of the Jewish minority by the

movement I went west." (based on an interview with Robert Blobaum published in: Piskała \& Marzec 2013: 69)

${ }^{14}$ Which otherwise blocked Soviet Russia's dream of launching a general revolution in Europe. With regard to the next 21 years (1918-1939), it is probably worth to notice the extremely efficient and conflict-free guarantee of women electoral rights (opening a short period of parliamentary democracy in 1918-1925) and the weakening of the municipal self-government under the influence of the increasing authoritarianism of Polish government. This short period of relatively stable urban development (like the city of Łódź, almost doubling the number of inhabitants over 21 years) was radically cut by the Second World War.

${ }^{15}$ Citing the example of Łódź, Arkadiusz Rzepkowski writes: "Along with the industrial development of the city in the 19th century, the ethnic structure of its inhabitants changed. While at the beginning of the 1820s, the Polish and Catholic population dominated in Łódź, the German and Protestant population started to dominate in the city at the beginning of the 1830s. It was the result of an influx of immigrants that had begun in 1823. The German element was definitely the dominant one among the craftsmen coming to the city. In the second half of the 19th century, there were migrants of mainly Polish and Jewish origin, the latter present in Łódź as early as in the 18th century. There were 6 thousand Poles (46.4\%), 92.4 thousand Jews (29.4\%), 67.3 thousand Germans (21.4\%), 7.4 thousand Russians (2.4\%), 1.3 thousand representatives of other nationalities (0.4\%)," (Rzepkowski 2008: 88) the total 
German Nazis after 1939 (Jewish community constituted a significant minority in the cities), as well as expulsions and the subsequent displacement of the German population after 1945 , forced dynamic population movements. ${ }^{16}$ The empty space left behind by the aforementioned minorities was occupied by other displaced people, including a significant number of villagers. The observation of sociologists studying this process seems very interesting; they talk about a peculiar 'ruralisation' of cities that took on the characteristics of its participants. This applies especially to industrial centres rebuilt and created from scratch. (Smagacz-Poziemska 2017) The process of ethnic change was so deep that it is legitimate to write about the ethnic and social homogenisation resulting from the exchange of population in cities from the late 1940s to the 1960s, which is especially relevant in terms of the so-called recovered lands. (examples: Wrocław, Gorzów Wielkopolski, Zielona Góra, Szczecin) The areas historically belonging to the Second Republic of Poland underwent fewer changes, but they struggled with a sudden drop in the number of inhabitants (supplemented by immigration and resettlement) and with a huge range of material losses, like the almost completely (in 80\%) destroyed Warsaw. Therefore, writing about urban communities before and after World War II in terms of continuity or social evolution is in many cases simply an error of judgement.

The subsidised and state-managed industrialisation formed a special imprint on the social shape of urbanised areas after World War II. This phenomenon was the implementation of the industrialisation project of the Polish People's Republic (Peoples Republic of Poland), where workers were to play a special social and creative role. The urban 'right to the city' can therefore be found again relatively late, when the processes of social disintegration and reintegration had a chance to come into existence again, probably only in the 1970s. It could have happened in the class tension between the 'new working class' and 'the new bourgeoisie,' except that the aforementioned

number being almost exactly 500,000. residents. 17 years later (in 1914), there were not much more Poles, i.e. about 50.9\%, Jews $32.5 \%$, Germans $15 \%$, and Russians $1.4 \%$. Regaining independence as a consequence of World War I (1918) resulted in, on the one hand, reduction in the population (data from 1921), on the other hand, a proportional increase in the number of Poles to $61.9 \%$ and, for example, a significant reduction in the number of Germans living in Łódź (to 7\%). (Rzepkowski 2008: 90) At the end of the Second Republic of Poland, public statistics recorded a proportional decrease in the number of Poles to $58.5 \%$, an almost unchanged proportion of the Jewish minority of $31.1 \%$ and a slight increase in the number of Germans (to 8\%). At the same time, the number of inhabitants increased dynamically over this period (341.8 thousand to 672.0 thousand). It is worth adding that in the interwar period, Łódź was a city with a dominant and growing quantitative position of workers as a professional group (55\% in 1921 to $63.6 \%$ over the next 10 years) and a slightly decreasing share of representatives of the upper and middle classes (Dzieciuchowicz 2014: 53-54). It is worth mentioning that the statistics describing the demographics of Łódź still indicated a very significant share of migration as a development factor, despite the deep crisis that the city experienced at the beginning of the 1930s as a result of the global depression. (Dzieciuchowicz 2014: 41)

${ }^{16}$ Similarly, in the case of Łódź, the period of World War II brought radical demographic changes, and not exclusively because of the war. The city's population decreased from 680,000 inhabitants up to 250 thousand (63.2\%) in 1945, including an estimated 170,000 Jews in the group of German occupation victims. As Jerzy Dzieciuchowicz says: "the pre-war Łódź, representing a melting pot of four cultures: Polish, German, Jewish and Russian, was erased from the history after the war.” (Dzieciuchowicz 2014: 70) 
classes came mostly from the same social trunk. The professional composition of the new bourgeois class or, to use the modern language, of the 'middle class' - city administration, representatives of the management segment of socialised enterprises, representatives of the educational system or other officials of the welfare state - was defined, like the workers, by a relationship of dependence towards the urban regime. For many years, the disagreement had been addressed to the hegemonic workers' party (the ruling party) or to institutions supporting it, such as the security services or the apparatus of preventive censorship. The social condition of the 'new workers' and the 'new townsman' was quite similar, both in terms of interests (resulting from the availability of resources, or rather their scarcity) and claims to subjectivity. Using the Marxist nomenclature, the class conflict was shifting towards the axis: the wage-worker class - the 'state capitalist,' which suggests that the distinction between classes was not justified in the socialist society (we are talking here about workers devoid of political subjectivity). This situation was also valid on a doctrinal basis, due to the claims of the ruling party to represent the interests and the voice of the working class. (Staniszkis 1992)

It seems important to highlight the fact that, as a consequence of the dramatic social history of cities, in Polish conditions not only it cannot be justified to write about social continuity but also about class continuity after World War II (with possible exceptions of Kraków or Poznań, two cities with long industrial and bourgeois traditions).

In the Polish context, it is similarly difficult to write about class rebellion in the classic Engelsian sense of the expression of 'right to the city,' as well as about youth rebellion from 1968. In these particular conditions, the potential equivalent of the latter was inspired by closing down the theatrical performance of Adam Mickiewicz's romantic poem Dziady in the National Theatre in Warsaw; the spectacle was judged as anti-Russian and therefore indirectly perceived as anti-Soviet. Thus, this revolt had not direct revisionist features, although it undoubtedly contributed to the emergence of the 'new-intelligentsia' opposition that rejected real socialism more and more firmly and explicitly.

\section{THE THIRD FACTOR: THE PROGRESSIVE REPUBLICANISM OF 'SOLIDARITY'}

As a result of the inability to articulate class interests and instead of a class conflict, a new conflict emerged between 'power' and society, sometimes referred to by sociologists as 'social schizophrenia' (Wnuk-Lipiński 1982) or 'social dimorphism.' (cf. Mocek 2016: 20$)^{17}$ In the conditions of a democratic society, it is difficult to understand its meaning. Thus, the fight for the 'right to the city' seems absurd on the theoretical ground and difficult on practical ground, due to the actions of the authoritarian state's extensive apparatus of repression. Moreover, lack of subjectivity (including urban sub-

\footnotetext{
${ }^{17}$ The concept of social dimorphism is described in the work Half-decay. Sketches in the sociology of systemic transformation, ISP PAN, Warsaw 1991, originally in Kultura i Społeczeństwo 1989 3-4: 53-72. The English version was published in a collective work: J. Koralewicz, I. Białecki, M. Watson (ed.): Crisis and Transition - Polish Society in the 1980's, Berg Publishers, New York - Hamburg 1987: 159-176.
} 
jectivity) brings the specificity of social self-organisation of the late Polish People's Republic closer to the models based on communal contestation, as we know from the period of the struggle for independence in the 19th century and in the first half of the 20 th century. On the one hand, these were more or less mass social demonstrations in large factories, taking sometimes the shape of uprisings or riots (as in Poznań in 1956, or in Pomerania region in 1970). On the other hand, we can evoke here elite acts of civil disobedience undertaken by intellectuals who co-created a democratic opposition with a left-wing, and then left-liberal tinge.

The distinction between these phenomena (mass social demonstrations and civil disobedience) has got a deeper foundation on historical and class base, which can also be read in the 'dichotomy' between: 'right to the city' initiatives' and 'urban social movements.' In Poland after World War II, these second type of activity reached the level of public visibility in the mid-1970s. Success of this process caused by effective cooperation between the democratic opposition and workers and was possible on the basis of the ideology ennobling the working class, followings the ideological core of the 'people's democracy.' The act of fighting for subjectivity was accomplished by forcing the legalisation of independent workers unions, thus announcing the so-called 'Carnival of Solidarity' (1980-81). It is no coincidence that this circumstance occurred in the main industrial centres, located in the largest cities (although outside the capital). The main events of this period were the authorisation to legalise the independent self-governing workers' unions Solidarność (NSZZ Solidarność) following the wave of strikes on the Polish coast in August 1980. The unions became a platform for self-organisation of the social movement (around 10 million workers joined the newly legalised independent union, while the entire population of the country counted at the time 36 million). Combining into one social phenomenon the revisionist attitudes of the PRL intelligentsia with a class social rebellion brought a surprising result. It was a very special variation of self-organisation that can be called urban on the one hand and communal-national on the other. (Brzechczyn 2016) Krzysztof Brzechczyn, in reference to the atmosphere of 1980, writes:

The involvement of the union at the end of 1980 and the beginning of 1981 in constant conflicts with the government and local administrative authorities created the need to develop a general program that would liberate it from the pressure of ad hoc actions. This accelerated the evolution of the union manifesto: from a restitutions-and-claims organisation, limited to defending workers' interests in companies and supervising the implementation of agreements by the authorities to an organization proposing economic and political reforms and taking active responsibility for co-ruling the country. The dilemmas were hidden in the frequently asked question at the time: what is 'Solidarity' supposed to be - a workers union or a social movement. (Brzechczyn 2014: 124)

The outlined dilemma is perceived here in the context of the evolution of the organisation, forced to assume the role of a 'revolutionary force.' However, it is equally legitimate to try to place the class/community dichotomy in the context of historical experiences and constant elements of the Poles' contestation discourse. A similar 
approach to the matter is justified by the ideological manifestos of the union. One of the first created ('Directions of the Union's activities in the present situation of the country. Theses for discussion') refers to values such as 'the best traditions of the nation,' ethical principles of Christianity, 'democracy's political calls' and socialist social conception. (Brzechczyn 2014: 124) The search for many foundations seems to be the consequence of understanding the relationship as an umbrella structure, the binder of which was the community tradition - also called republican - and not class identifications. The planned goal of the systemic change was to be a 'planning-market economy,' guaranteeing a higher level of rational functioning of enterprises, assuming less bureaucracy and management democratisation. (Brzechczyn 2014: 125) The forms of co-management of factories by workers were to play a large role in changing the model of managing the direction of democratisation. Workers' self-governments:

were to be (...) equipped with the powers allowing them to decide on the company's operations, directions of production and sales, production methods, the scope of investments and the division of the company's income. (Brzechczyn 2014: 126)

The doctrine of 'Solidarity' became fully-fledged in the Program of the NSZZ 'Solidarity' adopted during the 1 st National Delegates Congress (from the 5 to 10 September and from the 26 September to 7 October 1981). The change that took place there concerned the evolution of axiological references and the resignation from references to socialism; in its place appeared a reference to John Paul II's Laborem Exercens. This indicated the direction of the movement's evolution which, from the reformist vision of the workers' empowerment under the form of real socialism, evolved once again into a movement of community emancipation with a certain religious overtone. It was not, however, a complete retreat from the 'right to the city.' What seems to be crucial is the movement towards a vision of a state supported by workers' self-organisation in large workplaces, i.e. a form of multi-level, regional self-government and - largely forced by the intelligentsia involved in the union's work - a vision of decentralisation of power that provided the axiological foundations for the reform referring to the doctrine of subsidiarity that in itself had raised some controversy. (Cahill 2017) This reform took place 10 years later and derived from the social teaching of the Catholic Church. (Millon-Delsol 1992) The ideology of the union was therefore an interesting merger of workers' subjective and social demands, connected with the idea of self-government and constituting the meeting point of the intellectual and class-based vision of the workers' union and the social movement, with the additional claim of regaining the society's autonomy.

Let's quote the manifesto itself and refer chronologically to the 21 Gdańsk Postulates of the MKS. The first three include references to international documents ratified by the Polish People's Republic (Convention No. 87 of the International Labour Organisation), pledging the right to strike but also 'the safety of assistants' and referring to the constitution of the Polish People's Republic. The quoted legalism of the postulates indicates a specific, non-workers' context of the August 1980 revolt. Social demands do not appear in the document until the seventh manifesto (out of 
21). (Tygodnik Solidarność, October 16, 1981) As the 'Solidarity Workers Union Program' says: "history has taught us that there is no bread without freedom. We also wanted justice, democracy, truth, the rule of law, human dignity, freedom of belief, the restoration of the Republic of Poland, and not only bread, milk and sausages." (NSZZ Solidarność Program, 1) What draws attention, on the one hand, is the universality of the demands. On the other hand, one can easily notice the inclusion in one crucial sentence of postulates originating from very different axiological orders: from the liberal order (democracy, the rule of law, freedom of belief), through references to the state community (republican vision), and finally a slightly sarcastic indication of living needs at the end. In the following sentence the protest itself is defined, also in a rather characteristic way indicating what was not previously put in the axiological order, proper for the conservative perspective. As the authors say: "An economic protest had to occur [in the case of Solidarity] at the same time as a social protest; the social protest had to be a moral protest as well.” (NSZZ Solidarity Program, 1) What is more important, the vision of a social movement that explicitly presupposes the Sanation and moral postulates is directed against the authority that embodied the state power of the Polish People's Republic at the time. The subject of proceedings is obviously not the city as a form of territorial community organisation but the state structures seen from the regional perspective that in turn refers to the image of large workplaces as entities in the state management model. However, this is only a part of the concept of an evolving movement. The part that interests us the most at this point is entitled "The Self-governing Republic." The first sentence already mentions a 'comprehensive reform' that 'should lead to the permanent introduction of self-governance, democracy and pluralism.' The goals of the movement are, therefore, to "create and support independent and self-governing (autonomous) institutions in all spheres of social life, not only workers (NSZZ Solidarność Program, 1)." What is more interesting, the declaration of openness to various trade unions, students and industry organisations, is accompanied by the declaration of rejection of possibility to transform into a political party. In a way, this means rejecting the classic form of a class-interest organisation in favour of a universal (perhaps utopian) vision of radical pluralism in relation to the movement and empowerment of all organisations that follow very broadly defined Sanation goals. The core of the concept is the forms of employee self-government (in this context, however, the form of a cooperative is mainly referred to). For example, it is envisaged for workers' unions to have a legislation initiative and the possibility of passive participation in elections.

In thesis number 22, there is a more direct reference to local government as an instrument for empowering citizens in specific spatial communities. This empowerment is to take place through participation in elections and the far-reaching scope of the autonomy of local communities and their representation in the form of the 'Self-government Chamber' at the legislation level. Here, the aforementioned republicanism is probably the most visible due to the tradition of Polish society going back to the First Republic of Poland. This principle was present in the autonomist vision of trade unionists who, more than 'good (self-limiting) authorities,' expected direct representation of interests at the legislation level and influence on decisions at workplaces. 
The document from the beginning of the 1980s is perhaps the most spectacular record of the workers' will at the turn of the 1980s but also, which is perhaps more important for our analysis, an example of local self-government and self-government in the area of judicial power. (Thesis 24, NSZZ Solidarność Program, 7) Autonomy is therefore not class-related, but rather related to the place of residence and work as well as to the activity profile. Anyway, the key importance of workers in the described document is rather decentralised and perceived not directly, but through the image of self-governing communities with the primacy of the state as a space for the realisation of subjectivity. This specificity provides the basis for drawing historical and cultural analogies and renders possible to move on to the sources of the distinction between 'right to the city' movements and 'urban' movements in Polish conditions, paradoxically inclining (because the document created a workers' union) towards the latter. In other words, we witness here the creation of a movement that was a far-gone form of the collective empowerment concept, a form that questioned the ideology founding the PRL ('freezing' class relations, offering a fiction of class empowerment) and the project of state sovereignty. (Brzechczyn 2018) This movement, according to the author of the introduction, became the central myth that constructed Poles' community-based thinking about themselves, at least until Poland joined the European Union in 2004. It can be argued that such interpretation diminishes the usefulness of the implementation used in the sociological analysis to describe the Marxist sources of social dynamics (which could have contributed to the inability to understand Central European phenomena by researchers of social movements from other regions). The core of the social dynamics of 'Solidarity' generated disputes among researchers (Mielczarek 2019) and became difficult to understand for people from outside the Polish cultural context. (cf. Wójcikowska 2013)

Successive manifestations of social dynamics can be treated directly as a continuation of the functioning of the 'Solidarity' social movement. An example is the formula of Civic Committees established in the late 1980s for the purposes of self-organisation of opposition groups, in connection with the organisation of the election campaign during the first democratic elections held on June the 4 and 18, 1989. (Słodkowska 2014) The chance for real democratisation was related to the form of an agreement between the authorities of the Polish People's Republic and selected circles of 'Solidarity.'

Forms of self-organization also emerged in opposition to 'Solidarity.' (Wierzbicki 2016) In the first half of the 1980s (in 1983) a current emerged (referring to the classically understood 'right to the city'), associated with the generation of children of activists of the so-called First Solidarity: The Alternative Society Movement - RSA. This association was situated not only in opposition to the Polish People's Republic but also to the mass, 'pre-political' form of the 'Solidarity' movement. The Polish environmental movement also had its origins at that time. (Gliński 1996) ${ }^{18}$

\footnotetext{
${ }^{18}$ Which, by the way, has never gained enough mass support in Poland to, for example, achieve its independent representation in parliament.
} 


\section{THE FOURTH FACTOR: THE RADICAL ANARCHIST ALTERNATIVE WITHOUT CAPITALISM}

The phenomenon of the Alternative Society Movement (Kaźmierczak 2014; Grzelka \& Kula 2014; Wierzbicki 2016; Pluciński 2016, 2018), from where it was inspired by the Paris student speeches of May 1968, can be reduced to an attempt to implement the democracy formula at the city level which was not a widespread or obvious vision at the end of the 1980s, although it referred to the phenomenon of 'Solidarity' as a form of autonomic subjectivity (included in the concept of decentralisation of the state) and introduced a transgressive, new, local, urban, non-professional context. The magazine Homek, published as a non-debit newspaper in 1983-1990 (Brendt, Brzechczyn, Stybel, \& Waluszko 2013), is a perfect illustration of the philosophical profile of this milieu. However, it is worth taking a closer look at the social context of the RSA's emerging autonomy. As Przemysław Pluciński says:

Initially, the activists of the burgeoning RSA were fascinated by 'Solidarity,' primarily by its original anti-systemic character. The key factor here was the positive feeling towards the program of the so-called First Solidarity entitled 'The

Self-governing Republic of Poland,' containing clear syndicalist elements. (Pluciński 2016: 141)

The main premise for abandoning direct ties to 'Solidarity' was the formula (inscribed in the concept of the democratic opposition in Central Europe) related to 'self-limiting of revolution,' in other words, implementing the policy of self-limiting in terms of anti-systemic protests, with a purpose to reduce the social costs of open resistance. In the 1983 Manifesto, the creators of the movement write about this struggle:

[We fight] with all kinds of power. The RSA denies the need for any leadership. It assumes that a human being is capable of making decisions in a rational and proper manner while maintaining respect for himself and other people. (Kaźmierczak 2014: 243)

In a way, the aforementioned division had the status of a generational rejection of the 'old' by the 'young' and, in part, it was also counter-cultural, as it was related to the rejection of the conservative and religious character of the 'late Solidarity.' (Wierzbicki 2016: 322) The intellectual exploration of the movement was heading towards classical syndicalism and Edward Abramowski's philosophy of ethical socialism. (Pluciński 2016: 141)

At the end of the 1980s in Homek, libertarian content appeared more often; in this period one can also find a radical vision of urban democracy. The anarchist provenance was a consequence of the evolution of the movement's intellectual leaders. Originally, the adjective 'anarchist' was the epithet that the members of the RSA used against Solidarity activists (criticising their 'action-oriented' attitude); then, it became the emblem under which the activists hid in the mid-1980s. Anarchism was therefore not an ideology that defined the movement; it was rather a consequence of its evolution, resulting from the search for adequate self-identification. One of the contexts of this 
vision of democracy was:

strong valorisation of localism as the basic horizon of human existence and also possibly effective social activity, research for direct democracy's conditions. RSA members openly emphasized the search for links between urban space and the experience of life. The reflection on urbanity arose from the sense of a bond with the local, 'natural' or, at least in the imagination of the RSA members, a 'naturalised' urban environment. (Pluciński 2016: 143)

One aspect of this vision was to question the modernist idea of zoning space which, in their opinion, led to breaking the ties between work and leisure. The area of social life was to be the district, the scale of which would be adjusted to the subject's perception. This creates the construction of a city for humans; it also means a vision of grassroots self-organisation, in opposition to the image of a modernist city - designed and constructed by the elite. The attitude towards public spaces, which the activists of the RSA were literally fighting for by organising the space for free expression of views as in May 1989, seems also very interesting. They would also try to regain the city for their own vision. ${ }^{19}$ That phenomenon is also intriguing because of the historical perspective presented below:

A city for a man is a city in which the urbanisation process [...] is not rapid or advanced too far, and there is no development hypertrophy of the city. It is not a city that is too dense in terms of urban planning. (Pluciński 2016: 143)

In a way, this attitude may be the consequence of the specificity of the city, or rather the cities, where the movement operated (Three-city - existing together harbour cities: Gdańsk, Gdynia, and Sopot). However, this is not true. As Wierzbicki points out:

In the second half of the 1980s, new RSA cells were created across the country in Szczecin, Chełmno, Warszawa, Białystok, Zakopane and Sochaczew. Towards the end of the 1980s, RSA (already existing within MA / FA) together with a large part of political and counter-cultural formations and youth circles loudly protested against the policy of the 'Solidarity' trade union that opted for the agreement with the communist authorities. (Wierzbicki 2016: 323)

The organisation achieved nationwide representation, which does not mean that the scope of its influence reached the level of visibility in the public opinion. It was probably partly the consequence of the censorship still existing in the 80s and the necessity to operate within the informal circulation, and partly the rejection of the concept of 'alternative society' by the most influential opposition centres and then the main authorities.

It is hard to resist the impression that the image presented in Homek supplements the original vision of decentralisation we already know from the ideological document of 'Solidarity.' Nevertheless, it goes much further, giving far more prerogatives no longer to workers but to city dwellers, in opposition to the vision of people relying

\footnotetext{
${ }^{19}$ Pluciński refers to two articles: "Antifuturism, or a city for man by” Wojciech Mazur and Janusz Waluszko (issue 43 from 1989), and "City for man” by Klaudiusz Wesołek and Janusz Waluszko (no. 44 from 1990). (Pluciński 2016: 142)
} 
on meritocracy - the competences of experts (typical of the 'paternalistic' concept of 'Solidarity'). The formula of the magazine itself was an attempt to undermine the classic asymmetry between the sender of printed content and the recipient of such content. The magazine was distributed through people- distributors, who also acted as intermediaries in sending materials for publication. (Grzelka \& Kula 2014)

Strangely enough, the concept formulated by the 'young generation' of activists also covers the sphere of financing the neighbourhood community with the help of 'contributions' managed by local governments. Local self-governments (anticipating the existing auxiliary self-governments) were supposed to play an advisory role. The scope of financing from 'contributions' (forms of taxes) was broadly conceived, covering security issues as well. Unlike the concept of 'Solidarity', the role of the state was to be visibly reduced to supervising the sphere of communication. The city, as a self-government unit, would offer a range of benefits including, for example, social housing aimed at less affluent people. What is worth summarising here, in relation to the formulated utopia, is its 'de-nationalisation' and thus, in fact, the treatment of the state as some sort of Leviathan, a treatment typical of a libertarian orientation. This utopia also implied the universalistic need to secure the rights of socially excluded people and decommodification (which is still present in the left-wing parties tradition: Ziółkowski, Drozdowski, \& Baranowski 2020). The views of RSA activists did not create a fully coherent entity, but rather provided testimony of intuitive research (Pluciński 2018), located on the margins of the national public discourse or even trapped in local contexts. Therefore, it is impossible to recall directly any specific practical solutions taken from the concepts that arose in the 1980s in the RSA environment - apart from quite nebular analogies with the existing auxiliary self-governments ("neighbourhood council'). However, this is not the most important thing.

What seems crucial in this context is to notice the difference and the originality of their position in relation to the dominant narrative of 'Solidarity' and other phenomena of widespread youth self-organisation of those years. (Wierzbicki 2016: 318) On the one hand, it constitutes one of the identity pillars of the neo-anarchist movement in Poland, on the other hand, it may be almost entirely included in the pledges of 'urban democracy' written at least ten years later (Purcell 2008) and conscious of their limitations. (Purcell 2006, 2008) As Purcell suggests in the middle of the first decade of the new millennium, the neoliberal city becomes: "the local trap, in which the local scale is assumed to be inherently more democratic than other scales.” (Purcell 2006: 1921)

\section{THE FIFTH FACTOR: THE MELIORATIVE TREND OF 'CONCRETE NARRATIVE'}

The 1989 turning point is central to the recent history of the 'right to the city.' We are talking here about the consequences of the radical systemic change associated with the launch of the draconian process of marketisation (using the so-called 'shock doctrine'), to some extent reduced to mass privatisation of enterprises (previously socialised), as well as a deep crisis on the labour market. (Murell 1993; Sachs 1994) The shock doctrine has been a proving ground from the very beginning of the notion of the city, in which one of the aspects of restoring capitalism was the long-lasting deficit in 
consumption and high unemployment. With time, probably starting from the end of the 1990s, Purcell's diagnoses (the impact of neoliberalism on the city) also began to be valid for Central European cities. (Jacobsson 2015; Węcłowicz 2016) Oddly enough, from the very beginning, the reforms did not generate any serious forms of self-organisation and resistance, which can be explained in two ways: the involvement of the 'Solidarity' circles (now the ruling elite) in the reforms defence (Ost 2005) and the situation of the persisting economic crisis. This does not mean that there were no residual forms of resistance continuation or the radical involvement modus operandi, as we can see in the example of selected neo-anarchists groups, including the Poznan squad 'Rozbrat' operating in Poznań since 1994, also referring to the tradition of RSA. (Rosochacka 2017)

In the late 1990s, sociologists began to analyse the end of the systemic transformation (Ziółkowski 1999, 2000), which meant the emergence of a distinctive model of capitalism (some researchers evoke its similarity to Latin American capitalisms, Ziółkowski 1999) and the phenomenon of 'social immobility' - understood as the domination of individual strategies combined with the weakening of the dynamics of collective action (including the dynamics of the NGO sector growth) and the weakening of forms of social resistance. (Nowak \& Nowosielski 2005; 2006) It seems that a clear change in the social atmosphere took place in the second half of the first decade of the new millennium, with the emergence of activist organisations reflecting at first the so-called NIMBY syndrome (Staniszewska 2014), which coincided with the investment increase in Polish cities and the progressive improvement in the economic situation, the latter being attributed to the accession to the European Union. (Kubicki 2019) Once again, cities played the role of accelerators of investment processes - they became a training ground for conflicts and residents' resistance. (Jacobsson 2015; Pluciński \& Nowak 2017; Kubicki 2019, 2020) Whereas the sources of this new phenomenon were genetically related to the concepts cultivated by the neo-anarchist movement (referring directly to the concept of the 'right to the city'), the reaction to these forms of activity was rather ambivalent; nevertheless, some elements of a common lineage arose on the basis of historical analysis. (Pluciński \& Nowak 2017) This does not change the fact that the two perspectives quickly started contradicting one another. A good illustration of the essence of the dispute may be the discussion that accompanied the organisation of the First Congress of Urban Movements on June 18 and 19th, $2011^{20}$ where:

the concept of urban movement was treated very loosely by the organisers of the Congress. It was certainly not an instrument for a scientific description of reality, but rather a tool for building a political project and a common identity. (Kowalewski 2013)

\footnotetext{
${ }^{20}$ The meeting was attended by 100 representatives from several dozen organisations that considered the "trademark" of urban movements to be their potential representation. They came from a dozen, mostly large, Polish cities: Gdańsk, Sopot, Rumia, Gliwice, Lublin, Koszalin, Kraków, Łódź, Opole, Olsztyn, Szczecin, Warsaw, Wrocław, Sulechów, Gniezno, and Podkowa Leśna. The Congress was also attended by representatives of the Anarchist Federation, an umbrella organization representing the anarchist community.
} 
One of the leaders of the neo-anarchist movement in Poznań, where the first Congress was held, commented the situation as follows: "It is difficult to anticipate the political significance of this meeting, although I am afraid that it will be less than the organisers expect." (Urbański 2011) The premise of this distanced assessment was the hierarchy of the city's problems, dominant in the anarchist milieu, in which the theses formulated by the participants of the Congress and the discussions within it did not fully fit. The activist specified:

The proposed approach reduces the urban issue to the spatial and political level, whereas the social issues, once dominant in this approach, have been pushed to the background or not noticed at all. Housing issues, working conditions, unemployment, poverty, high rents, mass evictions, etc. were hardly noticed in principle. (Urbański 2011)

Therefore, he pointed out at least two issues: the evolution of the movement towards the elimination of specific content and going towards weakening the importance of the social issue, thus departing from the genetic, in the commentator's opinion, the perspective of 'right to the city.' However, his reproaches went even further: he accused the Congress of putting urban movements into the dominant discourse accepting systemic transformation, thus 'draining' the discussion about its consequences and not perceiving the real costs of neoliberal policy, which can be seen in the most emphatic example of Łódź:

It was said, for example, that the problem of some cities (Łódź) is 'depopulation,' i.e. a decline in the number of inhabitants caused by the emigration movement (mainly due to work-related issues), however this was not associated with deindustrialisation, i.e. one of the most significant phenomena we have been dealing with for over 20 years in urban areas. This, of course, could 'push' the debate towards the assessment of the Polish transformation and capitalism and it seems that there was no room for such discussions during the Congress. (Urbański 2011)

As it seems, this diagnosis was not far from the assessments of what city movements in the Congress edition should deal with - which was reflected in the city theses formulated at that time. ${ }^{21}$ Przemysław Pluciński, dealing with this issue in a systematic way, noticed a clear trend to depart from class-related orthodoxy inscribed in the concept of the 'right to the city,' a tendency to de-ideologise the concept itself and to attempt:

the production, by the bourgeois movements, of the dominant interpretations of what the right to the city is (and what is less important: what it is not) and how it should be legitimately interpreted. This legitimacy is sought in this case by translating the idea of the right to the city into the language of the so-called concrete narratives, seeking the raison d'être of (a)ideological neutrality. (Pluciński 2016: 136)

\footnotetext{
${ }^{21}$ Their record is available on the existing Congress website: https://kongresruchowmiejskich.pl/ tezy-miejskie-spis/urban-theses.
} 
As a result, he suggested that neo-anarchist circles were excluded from urban discourse. The axis of the dispute was, therefore, a kind of pragmatism of the consolidating movement (its genesis is associated with the years 2007-08): focusing on the instance in opposition to postulating comprehensive changes with a clearly anti-systemic and anti-capitalist feature. However, this pragmatism had other far-reaching consequences. The 'right to the city' ideology analysed in this introduction achieved some consensus with the dominant model of local government (which is accused of some authoritarian tendencies but at least it did not undermine the ideology's legitimacy) and, to some extent, also approved private property. The communities associated with the Congress, as the researchers of the phenomenon claim, accept political commitment and participation in local elections.

The concept of 'concrete narrative,' introduced by the main activists of the movement (Mergler, Pobłocki, \& Wudarski 2013), illustrates quite well the aforementioned pragmatism; it also portrays a kind of civic 'grassroots work' that can be described as intellectual, non-related to any political party and specifically pre-political. In their opinion, citizens implementing specific activities in the common space

discover that they are united by a common space, they suddenly understand that they can (and want!) to act together precisely for the 'right to the city' as a kind of general 'umbrella' under which there is a number of particular postulates. (Mergler, Pobłocki, \& Wudarski 2013: 37)

One of the ideological pillars of the movement, Lech Mergler, describes the specificity of the aforementioned pre-political nature by mentioning the fact that the 'concrete narrative' does not originate from general decisions about the world, human beings and society, but:

refers to specific situations, facts, places, problems in the city that visually, intuitively require action, intervention (...) We use great narratives when it is productive for solving these measurable problems, e.g. liberal ideas can be helpful in economic problems, left-wing reflection in social matters, ecology concept in matters of sustainable development, etc. (Mergler 2018)

The problem that can be seen in this ideology relates to what Marc Purcell described fifteen years ago as 'the local trap.' Among others, it should be perceived as the inability to produce a further-reaching coherent project in the frame of specific local management. This notion is not clear in itself, but it can be understood in the historical context and in the perspective of inheriting the vision of self-organisation. Purcell evokes a series of tacit assumptions that, on the one hand, are necessary. On the other hand, different understandings of politics by different people can lead to completely different results. (Purcell 2006) He says:

There is nothing inherently important about the urban scale in creating a more democratic society. Rather, any talk of reinvigorating urban democracy might be better expressed as reinvigorating democracy in cities. (Purcell 2006: 1936)

Thus, it is difficult to simply assume that, by choosing a specific type of grassroots action (the local scale on which we operate) without a clear picture of the whole, we 
will achieve certain goals. Nowadays, it can be clearly visible when urban movements oriented at defending particular interests (for example acting against revitalisation projects) intervene in public space.

\section{CONCLUSIONS}

The introduced distinction between urban social movements and 'the right to the city' initiatives is of fundamental importance when we look at the profiles of different forms of collective self-organisation. What draws our attention here is the fact that the former has usually been a part of the process of building the middle-class identity (which is an expression of the 'regional scale' analysis of the social modernisation activity) over the past 30 years. The latter are located in the area of discourse closer to the classical language of radical, left-wing provenance circles, the dynamics of which was catalysed by the crisis of 2008-09 in western and southern Europe, therefore fitting into a more universal European scale.

To summarise the proposed theoretical framework, in the long-term perspective (200-300 years) presented at the beginning of the introduction and in the medium-term perspective (the last several dozen years), the author aimed at pointing out the possibility of interpreting development modalities and proposed a departure from one vision of urban modernisation. In specific Central European experiences, this vision invites us to look for analogies, to be more precise, to look for the delayed effect of civic subjectivity articulation by granting rights or obtaining political representation at the local level, usually observed elsewhere. In the given context, it is difficult to talk about the premises of understanding the phenomena that accompany the inclination towards cultural continuity and the breakpoints resulting in:

(i) devastating disappearance of entire social segments (that happened in Central Europe and has not happened elsewhere);

(ii) emergence of new players, whose existence is a 'product' of the political process (this is well illustrated by the status of the 'middle class' and questions about class conflict in a neoliberal society, cf. Domański 2017);

(iii) external influences, such as the consequences of peace treaties after the great wars, the logics of democratisation, the NGO sector financed by umbrella organisations (Chimiak 2018) or the pre-accession and post-accession support system implemented by the EU.

As we can see, social reproduction can take place not through 'development,' innovation or borrowing, but also through support, imitation, 'cultural co-optation' through institutions and organisations - as factors of 'transpersonal' continuity. However, each time the forms of social self-organisation - the struggle for the 'right to the city' - are a reaction to accidental (event-related) crisis conditions or system tensions. From a narrower, regional perspective however, this approach requires references to nuanced (particularistic) theoretical concepts that look for premises of 'separateness.' It is a foregone conclusion that the essence of the idea is not to distinguish the scales 
of analysis for itself, but to adopt an appropriate scale where one can see the specificity that disappears at the level of broader generalisations, making social dynamics less understandable and causing simplification.

The proposed example of Polish and Central European experiences should not be treated as a manifestation of a belief in their uniqueness, it is rather about encouraging academic readers to look at social processes from a similar multi-scale historical perspective in order to be able to better understand each other, thus avoiding misunderstandings and stereotypical thinking.

As for the details of the contemporary phenomenon of urban movements and the 'right to the city' movements, we invite you to read individual texts from this volume that complement each other, exactly by using of different scales.

FUNDING: This research received no external funding.

CONFLICT OF INTEREST: The author declares no conflict of interest.

\section{REFERENCES}

Bogucka, Maria. 1981. "Miasta Europy środkowej w XIV-XVII w. Problemy rozwoju.” Roczniki Dziejów Społecznych i Gospodarczych 47: 5-24.

Bogucka, Maria. 2009. „Warszawa. Miasto i mieszczanin w społeczeństwie Polski nowożytnej (XVI-XVIII wiek).” Czasy Nowożytne 22: 9-49.

Braudel, Fernand. 1970. "History and the social sciences: The long term.” Social Science Information 9(1): 144-174. https://doi.org/10.1177/053901847000900107

Brzechczyn, Krzysztof. 2014. „Rzeczpospolita Samorządna. O ideowych inspiracjach programu 'Solidarności.”' Pp. 120-138 in Regionalny wymiar 'Solidarności' 19801981. Szczecin na tle kraju, edited by A. Kubaj \& M. Siedziako. Szczecin: IPN.

Brzechczyn, Krzysztof. 2016. "On the Evolution of the Political Thought of the Independent Self-Governing Trade Union Solidarność, 1980-1981: An Attempt at Interpretation.” Pp. 347-364 in Uncovering Facts and Values: Studies in Contemporary Epistemology and Political Philosophy, edited by A. Kuźniar, J. Odrowąż-Sypniewska. Leiden/Boston: Brill/Rodopi.

Brzechczyn, Krzysztof. 2018. "From Proletarian Revolution to National Uprising. An Overview of Conceptualizations of Polish Solidarność.” Humaniora. Czasopismo Internetowe 3(23): 15-50. http://hdl.handle.net/10593/25546

Brzechczyn, Krzysztof. 2020. The Historical Distinctiveness of Central Europe. A Study in the Philosophy of History. Berlin: Peter Lang.

Cahill, Maria. 2017. “Theorizing subsidiarity: Towards an ontology-sensitive approach.” International Journal of Constitutional Law 15/1: 201-224. https://doi. org/10.1093/icon/mox003

Chałasiński, Józef. 2020. „Społeczna genealogia inteligencji polskiej.” Retrieved September 20, 2020 (https://core.ac.uk/download/pdf/230558209.pdf).

Chimiak, Galia. 2016. The Growth of Non-Governmental Development Organisations in Poland and Their Cooperation with Polish Aid. Warszawa: IFiS PAN Publisher. 
Costa, Sérgio. 2006. “Deprovincializing sociology: the post-colonial contribution.” $R e$ vista Brasileira de Ciências Sociais 3: 117-134. http://dx.doi.org/10.1590/S010269092006000100007.

Lewis, Dijkstra, Enrique Garcilazo, \& Philip McCann. 2015. "The effects of the global financial crisis on European regions and cities.” Journal of Economic Geography 15: 935-949. https://doi.org/10.1093/jeg/lbv032

Dolenec, Danijela, Karin Doolan, \& Tomislav Tomašević. 2017. “Contesting Neoliberal Urbanism on the European Semi-periphery: The Right to the City Movement in Croatia.” Europe-Asia Studies 69(9): 1401-1429. https://doi.org/10.1080/0966813 $\underline{6.2017 .1385726}$

Fukuyama, Francis. 1992. “The End of History and the Last Man.” New York: The Free Press.

Domański, Henryk. 2017. „Stratyfikacja klasowa w Polsce: 1982-2015.” Pp. 16-40 in Klasy w Polsce. Teorie, dyskusje, badania, konteksty, edited by M. Gdula \& M. Sutowski. Warszawa: Instytut Studiów Zaawansowanych.

Domaradzka, Anna. 2018. "Urban Social Movements and the Right to the City: An Introduction to the Special Issue on Urban Mobilization." Voluntas: International Journal of Voluntary and Nonprofit Organizations 29: 607-620. https://doi. org/10.1007/s11266-018-0030-y

Dzieciuchowicz, Jerzy. 2014. Ludność Łodzi - rozwój i przemiany strukturalne. Łódź: Wydawnictwo Uniwersytetu Łódzkiego.

Eder, Klaus. 2006. "Europe's Borders The Narrative Construction of the Boundaries of Europe.” European Journal of Social Theory 9(2): 255-271. https://doi. org/10.1177/1368431006063345

Engels, Fryderyk. 1969. „W kwestii mieszkaniowej.” Pp. 229-321 in Dzieła. Vol. 18, edited by K. Marks \& F. Engels. Warszawa: Książka i Wiedza.

Frybes, Marcin. 2019. “Sociological Intervention «a la polonaise»: Alain Touraine’s Method in the Polish Context.” Przegląd Socjologii Jakościowej 15(3): 70-90. http:// dx.doi.org/10.18778/1733-8069.15.3.05

Gliński, Piotr. 1996. Polscy Zieloni: ruch społeczny w okresie przemian. Warszawa: Wydawnictwo IFiS PAN.

Grzelka, Monika \& Agnieszka Kula. 2014. „O języku publikacji Ruchu Społeczeństwa Alternatywnego („Homek” i druki ulotne).” Poznańskie Studia Polonistyczne Seria Językoznawcza 21(41)/2: 25-39. https://doi.org/10.14746/pspsj.2014.21.2.2

Harvey, David. 2008. “The right to the city.” New Left Review 53: 23-40.

Jacobsson, Kerstin. 2015. "Introduction: The Development of Urban Movements in Central and Eastern Europe.” Pp. 1-32 in Urban Grassroots Movements in Central and Eastern Europe, edited by K. Jacosson. Farnham: Ashgate.

Jezierska, Katarzyn \& Dominika V. Polanska. 2018. “Social Movements Seen as Radical Political Actors: The Case of the Polish Tenants' Movement.” Voluntas: International Journal of Voluntary and Nonprofit Organizations 29(4): 683-696. https:// doi.org/10.1007/s11266-017-9917-2

Kazepov, Yuri. 2008. “The Subsidiarization of Social Policies: Actors, Processes and Impacts. Some reflections on the Italian case from a European perspective.” Eu- 
ropean Societies 10(2): 247-273. https://doi.org/10.1080/14616690701835337

Kaźmierczak, Agnieszka. 2016. „Ruch Społeczeństwa Alternatywnego (RSA) jako wyraz dążenia do «wolnego» człowieka.” Retrieved September 20, 2020 (https:// eprints.oa.edu.ua/2837/1/28.pdf).

Kowalewski, Maciej. 2013. „Organizowanie miejskiego aktywizmu w Polsce: Kongres Ruchów Miejskich.” Przestrzeń Społeczna (Social Space) 3/2(6): 99-124.

Kubicki, Paweł. 2016. Wynajdywanie miejskości Polska kwestia miejska z perspektywy długiego trwania. Kraków: Nomos.

Kubicki, Paweł. 2016b. „Polskie ruchy miejskie: polityczne czy kulturowe?” Przegląd Socjologiczny 2: 65-79.

Kubicki, Paweł. 2019. „Ruchy miejskie w Polsce. Dekada doświadczeń.” Studia Socjologiczne 3(234): 5-30. DOI: 10.24425/sts.2019.126150

Kubicki, Paweł. 2020. Ruchy miejskie w Polsce. Kraków: Wydawnictwo Nomos.

Kubow, Magdalena. 2013. “The Solidarity Movement in Poland Its History and Meaning in Collective Memory.” The Polish Review 58(2): 3-14. DOI: 10.5406/polishreview.58.2.0003

Kuligowski, Piotr. 2015. „Gminowładztwo czy miejskość? Meandry polskiej irredenty przed powstaniem styczniowym.” Refleksje. Pismo naukowe studentów i doktorantów WNPiD UAM 11, wiosna-lato: 69-80.

Lefebvre, Henry. 1996. “The Right to the City.” Pp. 147-159 in Writings on Cities. Henri Lefebvre, edited by E. Kofman \& E. Lebas. Oxford-Malden, MA: Blackwell Publishers.

Lovec, Marko, ed. 2019. Populism and attitudes towards the EU in Central Europe. Ljubljana: Politika.

Maciejewski, Janusz. 1974. „Sarmatyzm jako formacja kulturowa: (geneza i główne cechy wyodrębniające)." Teksty: teoria literatury, krytyka, interpretacja 4(16): 1342.

Małowist, Marian. 2006. Wschód a Zachód Europy w XIII-XVI wieku. Konfrontacja struktur społeczno-gospodarczych. Warszawa: PWN.

Marshall, Thomas H. 1950. Citizenship and social class and other essays. Cambridge: Cambridge University Press.

Marston, Sallie A. 2000. “The social construction of scale.” Progress in Human Geography 24(2): 219-242.

Marzec, Wiktor. 2016. Rebelia i reakcja. Rewolucja 1905 roku i plebejskie doświadczenie polityczne. Łodź-Kraków: Universitas.

Mayblin, Lucy, Aneta Piekut, \& Valentine Gill. 2016. “'Other' Posts in 'Other' Places: Poland through a Postcolonial Lens?” Sociology 50(1): 60-76. DOI: 10.1177/0038038514556796

Mayer, Margit. 2009. “The 'Right to the City' in the context of shifting mottos of urban social movements.” City 13: 362-374. DOI: 10.1080/13604810902982755.

Mergler, Lech. 2018. „Apartyjne no ideologo czyli narracja konkretna.” Blog: Lech Mergler. Retrieved September 10, 2020 (http://lechmergler.blogspot.com/ search?q=narracja+konkretna).

Mielczarek, Adam. 2019. „Socjologiczne interpretacje ruchu 'Solidarności’ lat 1980- 
1981." Pamięć i Sprawiedliwość 33(1): 59-82.

Millon-Delsol, Chantal. 1992. L'état subsidiaire. Paris: Presses Universitaires de France. Mocek, Stanisław. 2016. „Od schizofrenii społecznej do światów równoległych. Przyczynek do autobiografii subiektywnej Edmunda Wnuk-Lipińskiego (1944-2015)." Civitas. Studia z filozofii polityki 18: 17-28. https://doi.org/10.35757/CIV.2016.18.01 Müller, Jan-Werner. 2017. Co to jest populizm? Transl. M. Sutowski. Warszawa: Wydawnictwo Krytyki Politycznej.

Murrell, Peter. 1993. "What is Shock Therapy? What Did it Do in Poland and Russia?" Post-Soviet Affairs 9(2): 111-140. DOI.org/10.1080/1060586X.1993.10641362

Niedźwiedź, Jakub. 2015. „Sarmatyzm, czyli tradycja wynaleziona.” Teksty Drugie 2015/1: 46-62.

North, Douglass. 1990. Institutions, Institutional Change and Economic Performance. Cambridge: Cambridge University Press.

Nowak, Marek \& Michał Nowosielski. 2005. „Od >próżni socjologicznej< do >społecznego bezruchu<. Uwarunkowania ewolucji społeczeństwa obywatelskiego w Polsce lat 80. i 90. XX wieku.” Pp. 267-292 in Państwo, samorząd i społeczeństwo lokalne, edited by K. Bondyra. Poznań: Wydawnictwo Wyższej Szkoły Bankowej.

Nowak, Marek \& Michał Nowosielski, eds. 2006. Czy społeczny bezruch? O aktywności i społeczeństwie obywatelskim we współczesnej Polsce. Poznań: Wydawnictwo Instytutu Zachodniego w Poznaniu.

Nowak, Marek. 2015. Teoria nieracjonalnego działania: socjologiczne studium na temat wolontariatu i społecznego aktywizmu. Poznań: Wydawnictwo Naukowe Uniwersytetu im. Adama Mickiewicza.

Nowak, Marek \& Przemysław Pluciński. 2017. „E pluribus unum? Źródła i specyfika ruchów miejskich we współczesnej Polsce.” Przegląd Socjologiczny 66(3): 115135. DOI: $10.26485 / \mathrm{PS} / 2017 / 66.3 / 5$.

Offe, Claus. 1985. "New Social Movements: Challenging the Boundaries of Institutional Politics." Social Research 52(4): 817-868.

Orzeł, Joanna. 2010. “Sarmatism as Europe’s founding myth.” Polish Political Science 39: $149-157$.

Ost, David. 2005. Defeat of Solidarity: Anger and Politics in Postcommunist Europe. Ithaca and London: Cornell University Press.

Owczarzak, Jill. 2009. "Introduction: Postcolonial studies and postsocialism in Europe." Focaal 53: 3-19. https://doi.org/10.3167/fcl.2009.530101

Padt, Frans \& Bas Arts. 2014. "Concepts of scale.” Pp. 1-16 in Scale sensitive Governance of the Environment, edited by F. Padt, P. Opdam, N. Polman, \& C. Termeer. Chichester: John Wiley \& Sons.

Pixová, Michaela. 2018. “The Empowering Potential of Reformist Urban Activism in Czech Cities." Voluntas: International Journal of Voluntary and Nonprofit Organizations 29(4): 670-682. https://doi.org/10.1007/s11266-018-0011-1

Piskała, Kamil. 2013. „Zapomniana rewolucja.” Pp. 16-43 in Rewolucja 1905 przewodnik krytyki politycznej, edited by K. Piskała \& W. Marzec. Warszawa: Wydawnictwo Krytyki Politycznej.

Pluciński, Przemysław. 2012. „Metroengelsizm, czyli o Engelsowskich korzeniach kry- 
tycznych badań nad miastem.” Nowa Krytyka 28: 103-121.

Pluciński, Przemysław. 2016. „Jaka demokracja miejska? Przypadek Ruchu Społeczeństwa Alternatywnego.” Nowa Krytyka 36: 133-150. DOI: 10.18276/nk.2016.36-08

Pluciński, Przemysław. 2018. „Poglądy gospodarcze Ruchu Społeczeństwa Alternatywnego.” Środkowoeuropejskie Studia Polityczne 1: 167-184. DOI: 10.14746/ ssp.2018.1.9

Pluciński, Przemysław. 2018a. "Forces of Altermodernization: Urban Social Movements and the New Urban Question in Contemporary Poland." VOLUNTAS: International Journal of Voluntary and Nonprofit Organizations 29(4): 653-669. https:// doi.org/10.1007/s11266-018-0007-x

Smagacz-Poziemska, Marta. 2017. „Badania nad społecznościami lokalnymi i sąsiedztwami w mieście - perspektywa socjologiczna.” Pp. 139-155 in Miejskie środowisko mieszkaniowe/Urban housing environment, edited by G. Schneider-Skalska \& E. Kusińska. Kraków: Politechnika Krakowska.

Purcell, Mark. 2006. “Urban Democracy and the Local Trap.” Urban Studies 43(11): 1921-1941. https://doi.org/10.1080/00420980600897826

Purcell, Mark. 2008. Recapturing Democracy. Neoliberalization and the Struggle for Alternative Urban Futures. New York and London: Routledge.

Purcell, Mark. 2011. "Possible worlds: Henri Lefebvre and the right to the city." Journal of Urban Affairs 36(1): 141-154. DOI: 10.1111/juaf.12034.

Riley, Dylan J. 2011. "Hegemony, Democracy, and Passive Revolution in Gramsci's Prison Notebooks.” California Italian Studies 2(2): 1-21. Retrieved September 15, 2020 (https://escholarship.org/uc/item/5x48f0mz).

Rosochacka, Agata. 2017. „Od rozbratu do zemsty / z Markiem Piekarskim rozmawia.” Pp. 167-182 in Poznań $w$ działaniu: Społeczne inicjatywy dawniej $i$ dziś, edited by M. Praczyk Poznań: Stowarzyszenie Czasu Kultury.

Rutkowski, Jan. 1986. Wieś europejska późnego feudalizmu. Warszawa: Państwowe Wydawnictwo Naukowe.

Rzepkowski, Arkadiusz. 2008. „Skład narodowościowy, wyznaniowy i językowy ludności Łodzi w Drugiej Rzeczypospolitej.” Przegląd Nauk Historycznych 7(1): 87-104.

Sava, Ionel N. \& Geoffrey Pleyers, eds. 2016. Social Movements in Central and Eastern Europe. A renewal of protests and democracy. Second edition. Bucarest: Publishing Office of University of Bucarest.

Sachs, Jeffrey. 1994. "Shock Therapy in Poland: Perspectives of Five Years." The Tanner Lectures on Human Values. Retrieved September 15, 2020 (https://tannerlectures.utah.edu/documents/a-to-z/s/sachs95.pdf).

Smith, Adam. 2007. An Inquiry into the Nature and Causes of the Wealth of Nations. Amsterdam, Lausanne, Milan, New York: MetaLibri.

Słodkowska, Inka. 2014. Komitety Obywatelskie 1989-1992. Rdzeń polskiej transformacji. Warszawa: Instytut Studiów Politycznych PAN.

Sosnowska, Anna. 2018. „Dlaczego warto badać zacofanie?” Roczniki Dziejów Społecznych i Gospodarczych LXXIX: 283-291.

Staniszewska, Monika. 2014. "NIMBY syndrome as an example of a social conflict with local characteristics.” Acta Innovations 12: 17-23. 
Staniszkis, Jadwiga. 1984. Poland's Self-Limiting Revolution. Princeton: Princeton University Press.

Staniszkis, Jadwiga. 1992. The Ontology of Socialism. Oxford: Clarendon Press.

Stark, David. 1994. "Path Dependency and Privatisation Strategies in East Central Europe." East European Politics and Societies 6: 17-54.

Szczepański, Jan. 1962. “The Polish Intelligentsia: Past and Present.” World Politics 14(3): 406-420. DOI:10.2307/2009359.

Thomas, William \& Florian Znaniecki. 1958. The Polish Peasant in Europe and America.” Vol. 1 \& 2. New York: Dover Publication.

Topolski, Jerzy. 1996. Jak się pisze i rozumie historię. Tajemnice narracji historycznej. Warszawa: Wydawnictwo Rytm.

Touraine, Alain, Francis Dubet, Michel Wieviorka, \& Jan Strzelecki. 1983. Solidarity. The Analysis of a Social Movement: Poland 1980-1981. Cambridge: Cambridge University Press.

Urbański, Jarosław. 2011. „Co to są problemy miejskie? Po kongresie ruchów miejskich.” Rozbrat.org. Retrieved September 15, 2020 (https://www.rozbrat.org/ publicystyka/aktywizm/2517-co-to-sa-problemy-miejskie-po-kongresie-ruchow-miejskich).

Wallerstein, Immanuel. 1992. "The West, Capitalism, and the Modern World-System.” Review (Fernand Braudel Center) 15(4): 561-619.

Wandycz, Piotr S. 1993. The Price of Freedom: A History of East Central Europe from the Middle Ages to the Present. New York: Routledge.

Wierzbicki, Marek. 2016. “The Alternative Society Movement (RSA) against a Background of Other Youth Formations of Political Opposition in the Polish People's Republic (PRL) in the 1980s.” Rocznik Instytutu Europy Środkowo-Wschodniej 14(5): 317-336.

Wnuk-Lipiński, Edmund. 1982. "Dimorphism of Values and Social Schizophrenia. A Tentative Description.” Sisyphus. Sociological Studies 3: 81-89.

Zarycki, Tomasz. 2005. „Podział postkomunistyczny czy postkolonialny. O naturze polskich podziałów historycznych.” Tygodnik Idei Europa 28(67): 11-13.

Zarycki, Tomasz. 2009. "The Power of the Intelligentsia. The Rywin Affair and the Challenge of Applying the Concept of Cultural Capital to Analyze Poland's elites." Theory and Society 38(6): 613-648. https://doi.org/10.1007/s11186-0099092-6

Ziółkowski, Marek. 1999. „O imitacyjnej modernizacji społeczeństwa polskiego.” Pp. 38-64 in Imponderabilia wielkiej zmiany: mentalność, wartości i więzi społeczne czasów transformacji, edited by P. Sztompka. Warszawa: Wydawnictwo Naukowe PWN.

Ziółkowski, Marek. 2000. Przemiany interesów i wartości społeczeństwa polskiego: teorie, tendencje, interpretacje. Poznań: Wydawnictwo Fundacji Humaniora.

Ziółkowski, Marek, Rafał Drozdowski, \& Mariusz Baranowski. 2020. „Utowarowienie i odtowarowienie w ujęciu socjologicznym: Próba (re)konceptualizacji.” Studia Socjologiczne 3(238): 53-77. DOI: 10.24425/sts.2020.132470. 


\section{BIOGRAPHICAL NOTE}

Marek Nowak is professor of sociology at the Adam Mickiewicz University in Poznań, Poland.

OPEN ACCESS: This article is distributed under the terms of the Creative Commons Attribution Non-commercial License (CC BY-NC 4.0) which permits any non-commercial use, and reproduction in any medium, provided the original author(s) and source are credited.

ARTICLE HISTORY: Received 2020-11-19 / Accepted 2020-11-30 
